
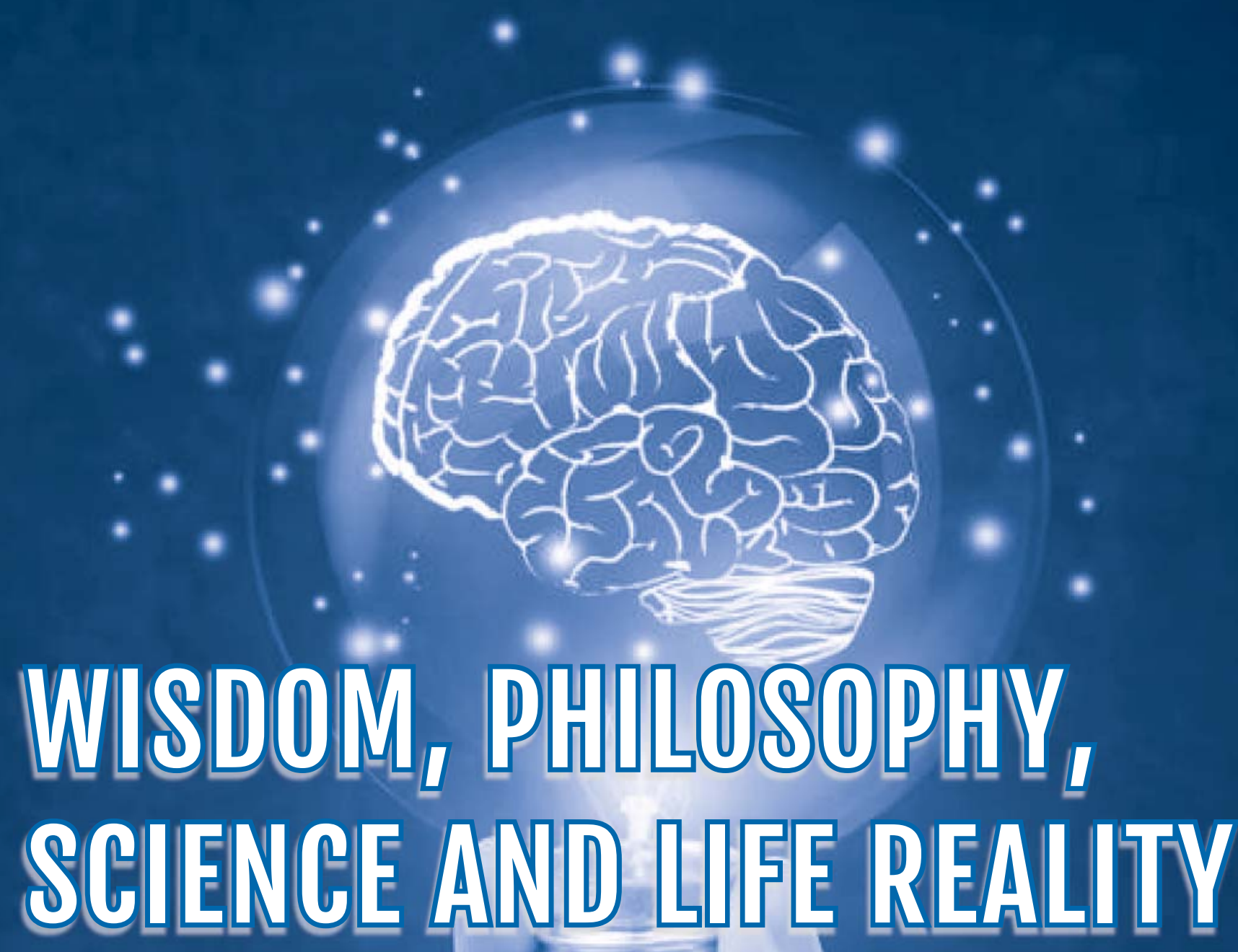

TLEORIES

Volume 1

Callixte Yadufashije 
Copyright: (C) 2020 Yadufashije C. This is an open-access e-book distributed under the terms of the Creative Commons Attribution License, which permits unrestricted use, distribution, and reproduction in any medium, provided the original author and source are credited.

Title:

\section{WISDOM, PHILOSOPHY, SCIENCE AND LIFE REALITY THEORIES}

\section{Volume 1}

Author(s):

\section{Callixte Yadufashije*}

Affliation(s):

Researcher in areas of medical microbiology and preventive medicine and Senior lecturer and director of research and consultancy at INES-Ruhengeri-Institute of Applied Sciences, Rwanda

Subjects: Philosophy

Received: 13 January, 2020 | Accepted: 23 January, 2020 | Published: 27 January, 2020

*Corresponding author: Callixte Yadufashije, Researcher in areas of medical microbiology and preventive medicine and Senior lecturer and director of research and consultancy at INES-Ruhengeri-Institute of Applied Sciences, Rwanda, Tel: +250788273428; E-mail: cyadufashije@gmail.com; cyadufashije@ines.ac.rw

ISBN: 978-81-943057-6-7

DOI: https://dx.doi.org/10.17352/ebook10117 


\section{Table of Contents}

$005<$ Abstract

$006<$

i. Positive impact comes from the beauty of the brain not from the beauty of the mirror-Dr. Callixte Yadufashije

ii. All respects, promotions and grades are nothing, if they don't show someone's contribution to the public- Dr. Callixte Yadufashije

iii. Time is the teller of true friendship"- Dr. Callixte Yadufashije

iv. I sometimes don't mind on how rich or poor you are to measure the level of your success, the traveled distance is the only good measure of any level of success-Dr. Callixte Yadufashije

v. If you want to be a good believer, don't believe anything before you believe yourself-Dr. Callixte Yadufashije

vi. Don't be late until life works for you, if life works for you, it will give you the remainder of others, you are not created to be given remainders, whoever you are, keep your value and work for your life - Dr. Callixte Yadufashije

vii. The final product is better but the way through which the product is reached is the bestDr. Callixte Yadufashie

viii. Don't compare your achievements with what anyone achieved, compare your achievements with what your dreams said - Dr. Callixte Yadufashije

ix. There are no miracles behind achievements except trying dreams-Dr. Callixte Yadufashij.

$x$. Facing a good or a bad character doesn't matter, it's all about learning-Dr. Callixte Yadufashije

xi. If you disrespect those who respect you, you are disrespected at all-Dr. Callixte Yadufashije

xii. To measure mass, we use kilogram, to measure length we use meter, to measure liquids we use liter, to measure yourself don't use anything else, you are the unit of measurement of yourself-Dr. Callixte Yadufashije

xiii. The root of success is not based on stopping challenges, it's based on overcoming challenges-Dr. Callixte Yadufashije

xiv. The worst colonizer of the inner man is selfishness-Dr. Callixte Yadufashije

$x v$. However bad was your past, a good present is an image of bright future-Dr. Callixte Yadufashije

xvi. If I couldn't stop life needs, life should always be difficult-Dr. Callixte Yadufashije

xvii. There is no any other important person in life rather than the one who gives you the time, listens to you and takes you to positive mindset-Dr. Callixte Yadufashije

xviii. Any death is sorrowful except death of ignorance-Dr. Callixte Yadufashije

xix. If love could be hypothetical, don't use any other test to test it, except love itself-Dr. Callixte Yadufashije

$x x$. If you are a good reader, the only good book to read and understand life is yourself-Dr. Callixte Yadufashije

xxi. I am not a fan of fails but I welcome challenges to learn more about myself-Dr. Callixte Yadufashije 
xxii. Those who experienced blandness of pain understand the taste of success-Dr. Callixte Yadufashije

xxiii. Do not work hard to satisfy people, work hard to fulfill your responsibilities-Dr. Callixte Yadufashije

xxiv. Positive answers are sometimes bad as negative answers are sometimes good-Dr. Callixte Yadufashije

xxv. We learn much of science to have knowledge, but we need to learn much of ourselves to be wise-Dr. Callixte Yadufashije

xxvi. Many people fail not because of capacity but because of determination-Dr. Callixte Yadufashije

xxvii. Simplicity is not always a measure of weakness but it's always a measure of validity-Dr. Callixte Yadufashije

xxviii. Wise people are always curious to know the way towards their dreams, but fake people always waste their time negatively criticizing what others are doing-Dr. Callixte Yadufashije

xxix. If life is not a straight line, fail doesn't matter. What matters is weakness to continue your life trajectory-Dr. Callixte Yadufashije

xxx. Achievements are not only measured through high positions occupied by an individual but also through his/her inspiration to the community around him/her-Dr. Callixte Yadufashije

xxxi. If value to others can't depend on humanity, it should depend on dependent life that every human being lives in-Dr. Callixte Yadufashije

xxxii. Truth doesn't always mean reality but reality is always a proof of truth-Dr. Callixte Yadufashije

$x x x i i i$. Planning before dreaming is like Present without future-Dr. Callixte Yadufashije

xxxiv. For a long time, I thought life as a circle but is not, life is unshaped and seems to be like a mathematical parametric equation with infinity values of parameters-Dr. Callixte Yadufashije

xxxv. Do not always use your struggles to show your pain, use your struggles to be a successful person-Dr. Callixte Yadufashije

xxxvi. A human being is a life hunter, and should hunt life all over the world. Thus, being white, black, tall, short or anything else doesn't matter. Do not be white, black, tall, short or anything else for your dreams to come true, but be wise and consider every one like your future investment-Dr. Callixte Yadufashije

xxxvii. Success is not about amount of money that someone's has, it's about achieving dreams-Dr. Callixte Yadufashije

xxxviii. It's always difficult to dig gold underground but it's a must to change History-Dr. Callixte Yadufashije

xxxix. Education is not a way of making life easier, it's a way of making life possible-Dr. Callixte Yadufashije

$x I$. If you want successful life through others, let them first be successful through you-Dr. Callixte Yadufashije

xli. Those who see others in the mirror of weakness are the weakest-Dr. Callixte Yadufashije

xlii. In Life, we should learn from others, but we should not copy their lives-Dr. Callixte Yadufashije

xliii. Struggling for respect no longer gives you peace, but struggling for peace gives you both respect and peace-Dr. Callixte Yadufashije

xliv. Do not do things because are easy to do, do things because are productive to you-Dr. Callixte Yadufashije

$x$ Iv. Books are silent philosophers, you can explain their philosophy through them and become a philosopher-Dr. Callixte Yadufashije

xIvi. You will never know anything until you know yourself-Dr. Callixte Yadufashije

xlvii. Nothing is good from tragedy except learning for bright future-Dr. Callixte Yadufashije

xIviii. No one can teach beyond his/her capacity of learning-Dr. Callixte Yadufashije

xlix. I don't know not because I don't know anything, I don't know because I am always curious to know-Dr. Callixte Yadufashije

I. People who fear fails are failers of life-Dr. Callixte Yadufashije

li. If you value who you teach, you learn by teaching-Dr. Callixte Yadufashije

lii. I don't have much to say on wisdom, but consider yourself wise if you are in touch with reality-Dr. Callixte Yadufashije

liii. There is nothing else differentiating believers and non-believers except imagination-Dr. Callixte Yadufashije

liv. Don't be the teller of lies about stories of others, if you can't be the teller of truth about stories of yourself-Dr. Callixte Yadufashije

IV. You won't learn anything from others, if you've learnt nothing from yourself! - Dr. Callixte Yadufashije

Ivi. During judgement of your crime, you can lie any judge from anywhere for you to be innocent, but you cannot lie your inner person the greatest judge of your crime!-Dr. Callixte Yadufashije

Ivii. When it comes to comparison, an eye blind person is wiser than a brain blind person-Dr. Callixte Yadufashije

Iviii. Wisdom is a creator of free thinking, while free thinking creates free mind and free mind creates inspiration-Dr. Callixte Yadufashije

lix. Out of Humanistic, friendship becomes nothing-Dr. Callixte Yadufashije

Ix. Remember that all people with light are not right people for you, you only need to know right people for you to have light-Dr. Callixte Yadufashije

\section{1 \& Acknowledgements}




\section{ABSTRACT}

This book contains 60 quotes and each one has its description that explain what the quote is about. These quotes give advices life realities. All quotes of this book can be taken in different areas of life or situations. Some of them have philosophical context and backgrounds are clear to make them understood. Some of quotes are centered on personal experiences of the author but everyone can take them in his/her own situation to use them in his own way. The content of these quotes can be the guide in different areas such us in leadership and administration, personal achievements, personal understanding, behavioral change, understanding of people's life, responsibilities success, and other different situation in global contexts. It is a good guide for young generation for them to build their capacity of understanding and prepare for their future. 


\section{Positive impact comes from the beauty of the brain not from the beauty of the mirror- Dr. Callixte Yadufashije}

Every one strives for positivity of life. We are in fail if we think that any beauty, shape, color or anything else characterizing physical feature of the human can be a criteria of a positive impact. Positive impact only comes from positive ideas and positive ideas comes from wisdom, wisdom also is in touch with reality. Reality has no negative impacts, if you want positive impacts look for people who are in touch with reality, they are always positive and their positivity is a creator of positive impact in everything. It doesn't matter on beauty and in normal conditions, beauty do not affect the brain, and any physical beauty is nothing without smartness of mind. Thus, do not waste the time detecting beauty, use your time detecting positive mindset. The positive mindset is always successful and will never fail leading to positive impacts of any positive plan in life. Divinity is not measured externally, it is through the mind and soul that someone is divine, listen someone's ideas before looking any physical characteristics. Many views of reality can be a proof of positivity and how it comes. Positive impact will not come because you are tall, short, black, white or any physical trait anyone can consider, it will come due to positive mindset of an individual. Thinking big and working in positive direction only create positive impact to anyone in the world. The reality is a leading cause of positive mind impacts, and positive minds is based on accepting both positive and negative outcomes in life, this doesn't matter on who you are, where you come from, or what you have, it depends on accepting reality as it is. Anyone can't be positively impacted, with negative mind, but negative outcomes, it doesn't mean that you are not positive. Once we engage our minds in positive, we are at the starting point of success, because success starts from the mind until you reach. Those who get success are already succeeded before in their positive minds and success is a positive impact from positive mind. Don't look someone's struggle to know if he/she can positively impact the community, if you want to know how positively he/she is, assess his mind and challenge his/her brain.

\section{All respects, promotions and grades are nothing, if they don't show someone's contribution to the public- Dr. Callixte Yadufashije}

Respects, promotions and grades are good in life. If you are respected, you feel enough in yourself. However, the reality of life shows that life do not end at one person's respect, no person cannot justify his respects and promotions. It is understandable, promotions can satisfy some one individually but no individual success is ever lasts. We need to the light of the world; we need to be significant in communities, and this one way of creating ways to our descendants. Contributing to neighbors is one of ways of investing to bright future. services offered to others should be given friendly and peacefully. No one is antagonistic to something better, all human beings have emotions and good emotions creates peace and wisdom in mind. Despite all respects and promotion, you have been given, no one will cite your respects if you have never contributed to anyone. Let's people cite your name and your good work, let's people benefit from your respect, let's people change their living conditions through you, your good air will continue existing even after your physical existences. Don't train anyone how respect is, train him/her to do respectful 
work, and through this he/she will be respected, not because people fear him/her but because he/she has contributed a lot to people's life. what makes you great is not because people praise you and fear you, what makes is how you get interest to others and strive for them to have what they require from you. A respected person works under his responsibilities, he takes care of people and respect the way they want him/her to help them. If people come to us, it is because we are there for them, they don't come to disturb us, they come to ask what are in their right and what are in their right are our responsibilities. Understanding of this clear reality is the beginning of respect, and rejecting this reality is rejecting the right respect, because any other respect out this, can be taken like fabricated respect. Fabricated respect cannot ever last, respects by outcome is the right respect and respect do mean that people should be allowed to praise your name. truly your name can be praised but not an obligation to do it. The good speaker of respect is what we do, not what we speak. Working hard to support others is the good speaker to any respect which will ever exist.

\section{Time is the teller of true friendship- Dr. Callixte Yadufashije}

It is common to be friends, everyone needs love and affections. This gives spiritual treatment of the mind. Friendship plays an important role to the promotion health, it is not only leisure. Having true friends is important and create peace in your living environment. Sometimes is difficult to distinguish friends, but is a good quality to protect our inner security. Friendship sometimes is temporary and most of people get surprised on this reality. There are what friends needs from you and they what you need from them, once this bond of needs breaks, hot friendship stops and continue general life like others. In our daily employment we meet people and live friendly, however, once one leaves, mostly friendship stops, this friendship is work associated friends. Life friends exist also, and these are friends that are inspired by your works and wish to stay with you over time. They don't mind for the distance of where you are, in the country or abroad, they always keep you in mind, time will tell you who is temporary friend or life friends. It is a responsibility of anyone to take care for any kind of friend, they all important in our lives, but also keep in mind that friendship require much attention, nothing is positive at all and time will show you everything. In any friendship be perfect on your side, but remember that inner man is hidden, it can take time to know the kind of friendship you are engaged in, but be perfect and wise to know your friends. It doesn't matter on what anyone needs from you if you can be able to deliver it to him/her, let's your mind be strong and free to discover environment you are staying. Take a time a talk independently with your friends treat them well and wait their outcome. Outcomes from friends will come with time, don't mind for how long, keep waiting, time will tell you the true friend. Do not be late to give up for fake friends to protect your inner peace and external environment around you, time assures any engagement of friendship and is the guider to wise people. friendship expresses the need for love for any person, despite challenges but everyone needs it. Do not waste much of your time thinking how engagement of any friendship leads you to bad outcomes, it is all about learning and we mostly learn from difficulties. You cannot suffer the same issues next time, if you have experienced it. Time is the teller but be wise to have true friends.

\section{I sometimes don't mind on how rich or poor you are to measure the level of your success, the traveled distance is the only good measure of any level of success- Dr. Callixte Yadufashije}

How do you calculate people's success? Is it through money that they have and invested? Is it through respected families and friends that they have? Is it through life history? It's all about understanding of every and each person to the level of success but any understanding do nothing to existing reality. In physics motions and travelled distances are taught. While thinking on measurement of success, I referred to Physics. Do not mind to where someone is from, his/her family status or history, consider how someone achieve what he/she needs, and consider where he/she get what he needs and also how things are easy or difficult should be considered. Anyone can achieve his/her level of success depending on her/himself not depending on anyone else. Even if you have the same achievement, level of success can sometimes be different accordingly. Two cars can travel from different distances to the same point but measuring how short or long of time used will depend on travelled distances in normal conditions. Do not mind on any 
level success you have if you have done what you were supposed to do. Avoid taking your success to see if it correlates with what others have, you don't know where they started from. Compare with yourself to see if what you have achieved are what you wanted. Compare what you have achieved with tragedies that you have faced. Thus any measurement of success should be calculated firstly basing on where someone came from, it could be far from the one you are comparing with. It sometimes takes a time to know where you are and where you should go, it's about unique identification, and all require to know yourself. Through ontological meaning, everyone has his own way to reach on success and everyone passes through different ways. No is the judge of what you have achieved or not, only the one to achieve knows why he did not reach his success.

\section{If you want to be a good believer, don't believe anything before you believe yourself- Dr. Callixte Yadufashije}

We all have what we believe, such in our works or in respective religions. This quote does not mostly refer to religious beliefs; it only refers to how we believe each other in our lives. Building our confidence in all corners is important. Nothing is enjoyable than self-confidence, and your confidence sometimes build confidence of your surroundings. The greatest poverty in life is not based on economic status, but on selfdetermination. someone could stay in stunting of the brain due to lack of self-determination which is also a source of self-confidence. No one can know who to believe if he/she doesn't believe him/herself. The way that someone believes in himself will create a mirror on who to believe. Self-believing is a key to who everyone can believe. "If you do not believe yourself, you will believe to others, but no one will believe you." Before starting any belief, self-believing is key. Creation of inner beliefs is the base of differentiating things on what you believe and who you believe.

\section{Don't be late until life works for you, if life works for you, it will give you the remainder of others, you are not created to be given remainders, whoever you are, keep your value and work for your life- Dr. Callixte Yadufashije}

We do not need to work in delays to face consequences of bad time management. Every human being should be responsible for his/her personal life. Whoever you are you have value to be independent for your life, before any one enters your life, make sure that you understand yourself, and be sure to work for your life independently. Plan for your life and be sure to draw a schedule for your life to be successful. Do not wait your life to tell you what you need, tell your life that you have already planned all needs. It is right of anyone to plan for successful life but It can be shameful to fail our inner planning for our better future. before anyone brings solutions to your life, make sure that you have your own solutions, and accept to implement any solution brought by anyone only if the fit your needs and come from the right way and the right person. Even if people can bring solution to you, you should be wise, they should bring solutions but sometimes with conditions. Before waiting anyone to come with solutions in life, your personal capacity to work for yourself is the highest guide. Do not wait anyone to bring solutions to you, strive to be a solution of people's life. To have a will to be a solution to your friends, peers and the community bring a good air of working hard. While working hard you are leading your life to the bright future. you work for others the same time working to yourself. It does not matter on who you are, your family background, your historical problems, you are enough not because of anything else, you are enough because you are a human who can think, work and implement. Your life is enough not because of anything but because you are alive. Work and try to satisfy what your life needs. You will never fail if you positively think the right way to guide life. do not wait remainders, no remainder can satisfy your life, every human being has capacity to satisfy his/ her life, do not think to receive remainders from anywhere. No one was created or born to be a slave of any one, and only slaves receive remainders of their slave masters. It is always difficult to understand how you could be responsible for your life, the life we live in is not easy but we need to think big in life for us to be successful. Do not limit your ideas and capacity because of anyone entering your life, you should here for them but be a man of decision for your life. your life is not a paper to be taken by wind from any direction. Your life is strong through you not through anyone else. Work for your life, do not wait anyone to give you 
remainders of his/her life.

\section{The final product is better but the way through which the product is reached is the best- Dr. Callixte Yadufashie}

Final products are good wherever they come from. It is with low percentage for many of us to think how the product took effort and sometimes blood of those worked on it. Nothing is good like achieving the product of your struggle and pain! It is a great pleasure to see products reaching us to facilitate our daily lives, however to ever last in life, a human being need to know how to make something. The first thing is to know how to make something before thinking on how to use or consume the product. The mind should be open to appreciate those who worked hard to make life possible through results of their effort. Nothing is impossible for anyone if is willing to work for positive impact of the community. Learning from ontological evidences is mostly significant for us to know how things are made. Tell me the way through which things are than is better than asking anyone to do things for you! No one is advised to train his/her mind to always receive what others have done, we should also learn to be donors. The way we learn to be donors, is the same way that our creative mind grow. The our we mostly interested to receive, the same way our mind lose the capacity of creativity and thinking big in terms of great achievement. This is not a principle of fighting against trading exchanges, economic exchanges of products, however, it is always better to have what you can exchange with others instead of checking what are coming to you. The capacity of a human should go beyond what he/she receives and learn to the producer to others, otherwise if those who produce products meet problem stopping them to make their products, receivers will face difficult challenges and this lead to both physical and psychological poverty. It is our interest to learn from what others are doing, but don't fail learning if you are learning, your value will increase through your offer to exchangers but if individual will wait to receive only, he/she will later lose what he/she has and longer think on the way to make his/her own product to be important to the world. Receiving the final products from other doesn't matter, however, how many times do you think on the way through which the product you always receive is made? How do you train yourself to be the producer of products? What are successful strategies do you think are best ways to be the producer to others? Do not put limitations that you can't make it, we all born the same way, and what makes us difference sometimes is how we see things and how our projection to future is constructed. How small or big the mind is, makes determination of someone's future.

\section{Don't compare your achievements with what anyone achieved, compare your achievements with what your dreams said- Dr. Callixte Yadufashije}

Do you know why you have achieved something? Do you know why you need achievement? What are guidelines for you to achieve what you want? Achievements are part of our lives, however achievement is big or small, be happy that you have achieved something. There are things that we don't consider in our life as achievements but they are. If you born and depend on your parents during your childhood, and later you grow and depend on yourself, is it achievement of life? I have never been able to buy clothes myself when young, I depended on my parents, but today I can buy it myself, this is life achievement. You traveled long distance by feet but you have a bicycle today, is it life achievement? Big achievements start from short ones. Achievements is not only based on big things that someone did, achievement is everything you did which is important for you or for others. It doesn't matter on the value of money that any achievement is, what is important is that you achieved and you will never need it like something you don't have. In life everyone should have vision, and to reach your vision you should plan. You plan based on what you want to achieve; you should not plan based on anyone else. Someone can fall in everlasting fails, if he/she plans based on anyone else. You are the planer of your plans, you are the achiever of your achievements, and your achievements should respond your dreams. Most of us fail, not because they can't succeed but because they plan sometimes what are not in their dreams. Do not plan basing on external influences of peers, friends or someone else, plan basing on yourself. Comparing your achievements with what anyone achieved sometimes matters, people think differently and everyone has his/her own dreams. If you have much achieved, it is fine, you achieved much because of your dreams, but whatever everyone achieved is 
due his/her dreams and him/herself knows whether he/she has much achieved. Compare with yourself because you are you, do not waste your time comparing with others, you have your own dreams, you know where you come from, and you know where you are going. Any achievement is listed in your dreams, not listed in dreams of anyone else you think you can compare with, and if not listed there, you are comparing your achievements with nothing. However, achievements of others are important, they give us a hope that things are possible, don't stop asking any advice from them if any, but be wise to implement their ideas in your own way. Achievements of other are lessons to others, there is no mistake from learning to others.

\section{There are no miracles behind achievements except trying dreams- Dr. Callixte Yadufashije}

For long time, I have been stupid to cerebrate achievements, and wondered why? I thought I am not the one achieving something at the first time, and my mind was kept on working more than cerebrations of what I have achieved. One day many people called me to appreciate my work for positive impacts, and thought myself that I am not a miracle for anyone, but I tried to work under what I have been thinking. I have never thought that I am beyond anyone and my inner stopped any proudness leading superiority feeling. Much noise came in my brain and I was feeling much of thought in mind. I came to discover something important while feeling the noise of the brain, what I discovered is that myself I am not a miracle, what I have achieved are not miracles, only one chance is to try what you think are important for you. No one is beyond anyone, we are all humans created or comes from anywhere else, but don't mind on anyone, take in mind that whatever we achieve are due to people. what is a miracle for you is not what you have achieved yourself, what is a miracle is that you have been able to think on what you need and able to achieve it? If you can achieve, you are a door to others, help them to open closed doors, they can achieve even more than you think. Instead of thinking on achievement as miracles you did, think opening door to other to build your future achievement. Nothing is a miracle behind achievement except trying dreams, and everyone can achieve something! No destiny in achievements, no poverty in achievement, no conditions in achievement, your value is the first achievement of your life, try your dreams!

\section{Facing a good or a bad character doesn't matter, it's all about learning- Dr. Callixte Yadufashije}

No one is always good at all, but also no one is bad at all! If I am not good at all, do I need to complain for any bad character that I can face? Ontological reality does not allow us to think always on good character, we should also think on bad character because this principle is for every human being. Now, who is a bad character and who is a good character? Do not point anyone, everyone has this quality of both good and bad character. Staring from your inner person, you have these two things, I point myself before pointing anyone else. A wise person should learn both in positivity and negativity. A wise person doesn't wait positivity for him/her to learn, to be wise requires positivity and negativity. Do not become bad via meeting a bad character, but learn to manage it and change it if possible. Remember that sometimes what is bad to us, can be good to others don't condemn any one for perception. It takes a while to understand this reality, mostly the inner person looks in positivity due to selfishness, but reality of the nature in which we live is a coordinator of this reality. Starting counting mistakes of anyone before managing them is like falling in everlasting darkness of ignorance. If two people are working together, they should manage each other to avoid conflicts from their behaviors and managing from each other is different from entering private life. the first bad character is myself before i start counting any bad character from anyone. This reality is not respected by the inner person, but also does not have capacity to disapprove it. I have been in darkness to know what is a good or bad character until I understand this reality. Mostly, people fail managing characters until they fail their professionalism, one barrier to them is that if I am given authority, I consider myself holy at all, and this is a real blindness I have never thought. I came to realize that both good and bad character are inside my will and the will of any human being. I totally denied principle of those who think are correct and point on others before pointing on themselves. At this reality, no reality will admire bad characters but every human being should strive for good to build peace on the planet, and this requires to fight with our 
inners. Why do I need to create a good environment for myself if we are more than one on the planet? You will never be peaceful if you want your own peace, you should count on peace of your community so that you get good air from the. Learning from both good and bad characters makes you wise but learning from only good characters makes you selfish. Learn in all corners to build your wisdom and create the inner peace.

\section{If you disrespect those who respect you, you are disrespected at all- Dr. Callixte Yadufashije}

Human nature always search for respect. This is a will for every human being, human being wants to hear people positively commenting on him/her, a human being wants to hear people fearing him/her and these all make him/her proud. You are lucky to be respected and any respect if managed can lead to achievement of your dreams. However, most of people have small capacity of thinking, they think that if someone takes a respect to you, he/she should be disrespected, if you consider those who respect you at this manner, you totally change your respect status. People will respect you not because they are disrespected but because you contributed to life. clearly most of us contribute to life but the way we behave after people praise our contribution sometimes become worse and lead to disrespect and create conflicts. It doesn't matter on the status of who respect you to respect him back. Value those who take their time to respect you, to think on you, give them moral support to maintain your status and themselves. You will never have any respect if you disrespect those who respect you! If you disrespect the one who respects you, may be they will fear you but fearing you means nothing. Considering our people is for great you, we are great because of them, those who we think are weak, they are the same people who mostly cite our names. Determination of the value comes from your environment and environment gets information from yourself. If people respect you, is because of your positive value, be always positive to them and take them as valued people to maintain good air of environment.

\section{To measure mass, we use kilogram, to measure length we use meter, to measure liquids we use liter, to measure yourself don't use anything else, you are the unit of measurement of yourself- Dr. Callixte Yadufashije}

In Physics and mathematics, we always measure physical quantities, and this is not something we need to only consider in sciences, but also in our lives. The only big fail that we face in life is to take others as our unit of measurement before we become the unit of measurement of ourselves. No one is the unit of measurement of anyone in normal conditions. Everyone knows him/herself, everyone knows the level, quantity and quality of what he/she needs, that's why no one can be your unity of measurement, no one knows your satisfaction at all. The quality and quantity of what you need are based on your inner, who I am to be your unit of measurement? What you want are always based on you, not anyone else, your quantity and quality are all based on your inner satisfaction, and if your satisfaction is reached, no one to judge you on quality and quantity you have received. The judgement of the quantity and quality you need is based on yourself, not anyone else, and any one can be considered mad is he/she thinks to be the unit to measure and judge the quantity and quality of any one's needs and satisfaction. A normal person understands his/ her inner and outer needs both in terms of quality and quantity, and no support needed to know if your satisfaction is attained, you know yourself. It is wasting of time to think on the level that any one's needs, let him/her at least tells you what he needs only if you have a contribution to offer for his/her satisfaction. You are the quantity of your quantity, you are the quality of your quality, generally you are yourself. You're the measure of what you need no one else can be ready and if you try to engage anyone to measure what you need; this is a remind that you are in a wrong way. Do not try to engage anyone to tell you what you need, engage him/her only if you have already identified what you need and seek any support from him/ her if needed. It can happen that anyone can feel proud to be the measurement of your life, tell him that he/she is doing what he/she is not supposed to do, tell him that he/she is wasting his/her time, you know who you are, you know what you need, and you are ready to calculate everything for your satisfaction. All people, ignoring their races, ethnicity, social classes, countries, or anything characterizing them are valued 
and they have to measure their value, they understand their value, and they understand themselves. It is responsibilities of anyone in the world to measure what he/she needs, and remember that if you fail measuring your need, any one will help to measure with wrong indications.

\section{The root of success is not based on stopping challenges, it's based on overcoming challenges- Dr. Callixte Yadufashije}

No success can be spoken without challenges. We speak success because we faced challenges. In human ambitions overcoming challenges is the first responsibility. Challenges show us if can or not, challenges try our capacity. If challenges come to fight against you, do waste your time to stop them, use your time to overcome them and come up with victory. Challenges are industries to make us good products, challenges are always reminders of what we should do and what we should not do. Do not fear that challenges are there. Tell challenges that you are there to fight, do not tell challenges that you are fearing them. Without challenges, no one can cerebrate success and individual without challenges cannot understand how wise and strong he/she is. Actually challenges mostly come to make fails, however they determine success of anyone who faced them. You are no longer a successor if you no longer face challenges. The true secret of success is yourself, and how you manage challenges. If challenges are to fail you, you should be an ever winner of challenges. Challenges comes from everywhere, they can come from friends, nature, even in yourself. Challenges can create fails; your dreams are creator of everlasting success. Do not mind on how difficult challenges are, look the heaviness of your dreams, and this will make you strong to overcome any challenge comes to your life. we succeed not due to absence of challenges but because we have dreams. Anyone can overcome challenges, it doesn't matter on how big, short, race, anyone is, what matters is what you have in your dreams. No challenge is short to overcome it easily, but also no plan should be weak to fail reaching dreams. Plans will fight challenges to reach dreams. No challenge is painless but also no success if for nothing. However, if anyone fails to overcome a challenge, it is not a time to be weak and fail forever, learn from your fail and come with new strategies to not face the same fail in the journey and the war of life. analyze previous fails for future success. If winners exist, failers also exist, although, no one is a winner or a failer at all. Work to be a winner and take fail like accident you can face in you travel.

\section{The worst colonizer of the inner man is selfishness- Dr. Callixte Yadufashije}

Most of outer man is influenced by the inner man. A human being strives to make better for him/herself, a human being always wish to influence others, a human being wish for visibility, a human being thinks for himself before thinking to anyone else. All mentioned characteristics that show our inner man willing are all important to anyone, however, it can lead to fails if it becomes a colonizer of our inner. Selfishness do not mean that you cannot think on yourself, however, we broadly grow in terms of thinking through our responsibility. If anyone is responsible for him/herself no longer think big. Our inner responsibilities are totally different from our responsibilities mentioned our employment contract. While signing an employment contact, there is a physical contact which is a written paper, what we do to fulfill our contact requirements should be done based on inner contracts. Despite fulfilling employer requirements, employees serve the community and community should benefit from them. Employees should not only to fulfill responsibilities, but also creating a good air to the people you serve. The inner man contract reflects to the way we fulfill the physical contract responsibilities and how we serve people when providing services to them. If anyone succeeds from selfishness, he/she will understand the theory of life creation through your daily services provided people. who you serve is your good life creator of the future. selfishness will never allow you to make a big value to others is it colonizes you, selfishness will never help you to fulfill your inner contract, selfishness will destroy your senses of wisdom, do not allow selfishness to colonize your senses, let your mind be wide, think to serve people as you serve yourself. Selfishness can put barriers to your achievements, it actually causes inner accidents, and people will never feel your work or services if given with selfishness. Consider life of others as you consider yours, through this, you succeed from selfishness. 
However bad was your past, a good present is an image of bright future- Dr. Callixte Yadufashije

Sometimes previous and past history is traumatic to those who passed through it. Past and previous life history has been a fact for many people to go through their dreams, they always think on their previous life, and some people who don't wish their good achievements always mock at them by means of previous history despite a good present. Your past is not the determinant of your future, and longer can interest you. It is understandable that anyone can face disturbance of his/her bad past even everything is well in the present, but if you have overcome your past, why do you take your ears and brain to those who remind you about your past for the purpose of decreasing the value of what you have achieved? No one will never be safe at all in everything he/she achieved but remember that you are yourself, no one to be the speaker of your achievements, achievements will speak for themselves and will tell story about you. Consider who you are in the present than considering who were in the past. Who you are today clarifies who you shall be in the future. It is also significant to remember the past not to decrease the value of what we have achieved but to learn from the past for future success. Consider your present and do not mind to anyone commenting negatively basing on your past history, work hard and succeed challenges, do not fight with people, fight with what you want to achieve in the future. past events ended with the past consider the present to future. in life people face different events and no one can stop anything to reach him/her when arrive, some of them came because of our choice and others came randomly to us. It does not matter how they stressed us or how they showed bad image to our names if we learnt much from them, and avoid to never happen in the present and future. if anyone tell you about your past for the purpose of hurting your future, do not waste time with him let him waste the time on your past, instead using his/her future to build his/her capacity.

\section{If I couldn't stop life needs, life should always be difficult- Dr. Callixte Yadufashije}

Why do I want life to be easy? Do I understand what easy life mean? Life will never be easy to anyone in this world but it can be possible only if we stop needs. It is through what we need that life becomes difficult, a human being made life possible in the world and the same time, he made life to be difficult. If anyone wants life to be easy, he/she should stop life needs. Life becomes difficult because of what I need, and I mostly want life to be easy without reducing what I need. Before thinking on easy life, we should think to our needs. Each and every person has the level of life difficulties, people are equally share the same life challenges and difficulties, everyone has what he/she needs due to needs, and is through these needs that the life get complicated. The reality shows no facilitation to easy life, life needs many things for individual survival. If anyone reaches success in life, it doesn't mean that the life is easy for him/her, he invested much of energy to reach the success and satisfy his/her needs, and will never stop working because a human being is always under needs and satisfaction, no end of needs and no last level of satisfaction that is why life continues to be difficult until we end our time of existence on the planet. Don't invest your brain to make life easy, invest your brain to make life possible. The way we make life possible leads to success of what we need but the way we make life easy contribute nothing to our understanding us we focus on making things easy. We always need, we should always invest our physical and mind effort to reach what we need and each and every human being has his/her own ability to reach what he/she needs. Making life easy is mostly understood with those who don't understand the reality of the nature, if the nature change, why do we think on easy life? if climate could change why do we waste our time thinking on easy life? the problem is not how difficult life easy, the biggest problem is how you plan to adapt on life issues. Strive to reach your needs at your level not at the level of any one, if you strive to reach your needs at the level of others, life will fail you and this fail is the worst one in life. every human being should accommodate his/her life, and any modification should be based on him/herself. We always need to live; we should fight for needs not for easy life. 


\section{There is no any other important person in life rather than the one who gives you the time, listens to you and takes you to positive mindset- Dr. Callixte Yadufashije}

The hardest exam in life is to know who you need for any step of life. some people lie themselves on who they need, and engage highest conditions on the person they need life. who do you need and why do you need him/her for him/her to come in your life? what are your selection criteria for people you should work with? Do you consider rich people in terms of money or ideas? To know who you need in life you only need to be yourself to know who you need. It doesn't matter on any criteria you engage on who you need if your choice is based on yourself. Nothing will be difficult if you understand who you are and if you don't understand who you are, you fall in fail of identifying who you need and what you need from him. Although, identification of who you are and who you need is not enough for you to be successful, we also need to know if who we need has time for us and is through interaction that you achieve what you want from him/ her. Take your time and listen to who you need, and harvest from his/her capacity for you to grow, if he/ she point exactly on what you need, take note and be ready to discuss much or to ask much for you to have clear direction. The first achievement is that the person you need accepts to give you his/her time, and ready to listen from you and be free to direct you to positive mindset. Only positive mindset is a key to be successful, and is better than anything else that you can be given. Positive mindset leads to positive thinking and positive thinking leads to positive achievements and positive achievements show the success of your dreams. Learn to be positive in both positive and negative circumstances, do not be positive only in positive situations, be yourself and don't be changed by wind ideas. The greatest person for you is the one who can give you his views, not based on what you think but based good guidance. Some people fail because of false identification, and discourage their future achievements. No one is short for you to learn, no one is old for you to be strong, no one is young for you to understand, everything is based on you and what you wish to achieve. Be you to reach your goals and dreams, and the person who can offer the time, listens to you and gives clear direction, is the right person to work with. Your success is based on yourself and who or what you need to achieve it. Those who are wisely successful are needed to learn from them.

\section{Any death is sorrowful except death of ignorance- Dr. Callixte Yadufashije}

Ignorance is killed through knowledge and buried through wisdom. Anyone can be successful through killing and burying ignorance. A human being should understand the reality between knowledge and ignorance for them to be wise. All necessary things leading to ignorance are very easy and simple to be achieved, but to be knowledgeable requires sweating until you succeed. Not death is for cerebration, but death of ignorance should be celebrative to everyone. Where ignorance is there no peace, no development, no achievements, no reality, no wisdom, and nothing positive can come from ignorance except destruction physically and psychologically. Ignorant people think that they are enough for themselves, wise people think that they sometimes need other to achieve what they want. Ignorant people think that they are the best, wise people don't mind on how best they are, they always focus on their responsibilities. Ignorant people think that they know everything, wise people are always curious to learn. Ignorant people focus on themselves, wise people mostly focus others. Ignorant people do not wish achievement to others, wise people support others to achieve. Ignorant people speak much to show how knowledgeable they are, wise people let the work speak in their behalf. Ignorant people ignore people they think are low, wise people take the value to everyone, ignorant people create friendship with their bosses, wise people create friendship with his/her responsibilities. Ignorant people are always interested to confirm their truth; wise people wait the truth confirm itself through outcome. Ignorant people are bosses but wise people are leaders. However, no one is created to be ignorant, everyone can be wise. No one born to be ignorant or is about choice. We should work and strive for a good mindset for us to wise and be different from ignorance. Death of ignorance is the greatest work that someone can do, all root of problems is due to ignorance its death is itself success. We can lose friends, brothers, sisters, and get a long time sorrowfully but we will have an everlasting happiness if our ignorance dies. To have knowledge requires searching for it, it can't come randomly and 
avoid thinking that what you have is enough. Experiencing knowledge in your work, interacting with others, feeling different environments, thinking with positivity lead to wisdom and wisdom leads everlasting peace. Kill ignorance to be knowledgeable, and burry ignorance to be wise. If ignorance is buried, the bad smell from it will take you again to ignorance.

\section{If love could be hypothetical, don't use any other test to test it, except love itself- Dr. Callixte Yadufashije}

No provisional love exists, and if I can think to love provisionally, this love means in nothing in a human needs. Love is actually a human need but love with necessity can lead to mind stresses. All of human beings have friends, and love support much our psychological needs. To enjoy love with your friends, having a good relation is more than important. Hypothetical love creates problems between friends and cannot take long with this condition. Hypothetical love is conditioned and need to be tested. If two friends are together in love, there are things to be avoided to protect doubt of love between themselves, otherwise love could bring conflicts between friends. Be honest to your friend and do not confuse him/her to prevent doubt of love. Give him/her the time and make sure that you understand him/her. Be with friend in peace, and struggles, and in case the friend is difficulties, this is the good time to take care of him/her. If you take your time to visit your friends in difficulties, it shows him/her your true love and this love will have no doubt at all and will last longer than expected. Sharing everything between real friends is what love means, and if love is different from this reality, it can be doubtful and creates hypothesis between friendship. Some people doubt on their friends because of behaviors of their friends to them and others doubt on their friends because of their level of satisfaction in love. This doubt in friendship leads to love testing where one of friends decides to test his/her friend for him to make sure that his/her friend loves him/her. However, any one test the love from his/her friend, do you love the one that you are testing? At which level? Love testing, is because you want causes from him/her? Testing, is it because you are selfish? Ask yourself why you conduct a love testing to someone instead of taking your time and discuss individually. Some of us are selfish and expect love to other that ourselves cannot offer. Love should not be a debt, if you have done many things to your friends, don't expect much from them, even if they can do the same sometimes if they can. If anyone expects many from his/her friends more than expecting many in what he/she can offer to them, his/her love now becomes hypothetical and more doubtful. Be a good friend before expectations. And if you know your friends well, you should know their capacity, you know what they can offer and you know what they have. A good friend asks him/herself on what he/she can do for his/her friend than asking on what his/her friend can do for him/her. I can take myself selfish if I take the time wondering what my friends can do for me instead of wondering what I can do for them. Thus, however testing love to anyone, test yourself before testing your friends. Check your honesty in love, and through honesty, you will know everything about love that you are in. Do not conduct love testing to stress your friends and it is not easy for you to measure love feeling to others. In every friendship that we engage in, we are human beings and any can be mistaken in love, we should learn to forgive our friends and provide advices than thinking on test their love because of mistakes. Use love to test love, using any other test is due to selfishness of your inner. Engagement of love is big project in a person's life, it asks the friendship engager to ask both solutions and challenges. Challenges should come from any source in friendship. Avoid taking your friend like an innocent person, he is like you, and you are all exposed to the nature.

\section{If you are a good reader, the only good book to read and understand life is yourself- Dr. Callixte Yadufashije}

Book are source of knowledge and skills and readers mostly concentrate on books of their domain of interest to have enough package in their areas of specialization. If is biologist, he/she reads a book related to biology, if is physicist, he/she reads books related to physics, Mathematician reads book related to mathematics, Chemist reads books related to chemistry and all are source of knowledge to their specialties. However, there is another important book that sometimes people neglect. This book is known as book of life. Book of live contain everything concerning people's life and every and each person begins to write 
his/her book since reaching the planet. No one can fail writing this book, all categories of human being have this important book of life. a human is made of his physical appearance and his/her inner person. However, there is another hidden part in the inner person, that tells about these books of life. people read different history, biological books and others to understand life but they forget reading a good book they wrote themselves to understand what life is. We sometimes read life others to understand life and we forget that we have our own books explaining well what life is. Take your history of life, go through it from the beginning to the end you will understand what life is. Since any one born, he/she pass different events, you met many things bad or good, you have met people and did better or bad, these are some of things that helps anyone to understand life. life is not understood well through anyone else except individual's life. remember you past, present and if possible design the future, this is how most of us start learning about life. in life people meet difficulties, tomorrow you meet a good life and they interchange like this. You can meet someone today and you think you will never meet again, then, you later meet him/her where you have never thought to meet him/her again. Life is actually a mysterious design, that anyone can analyze and know what it means. Nothing can explain life than individual life. anyone can interpret life basing on his/her own experiences, but you're the one to understand it in your life trip. Generally, a human being should manage life him/herself, it doesn't matter at which level you are managing your life if it fits yourself. Nothing is better than knowing yourself for future determination.

\section{I am not a fan of fails but I welcome challenges to learn more about myself- Dr. Callixte Yadufashije}

Each and every plan should be for success. Realistically, the way through success is reached can be interfered. Empirically, there is nowhere to escape what can challenge you, and challenges mean nothing to a winning person. Challenges mean nothing for winners if they think they can stop a winning person to win, however, challenges are like a boat that support passengers to cross the ocean. None can will without challenges, but challenges are different from a person to another. If any person engages any winning activity, challenges cannot be a barrier to him/her. No one who succeed due to absence of challenges, and this will never exist. For those who believe in Jesus, they better know that he faced challenges and temptations to reach on his mission in the world. He died and resurrected. In challenges, we measure our capacity and we learn more from challenges. Do not fear that you will fail, take your work the way you should do it, learn to work under difficult circumstances and adapt to any situation for you to be strong in what you are doing. No one will call challenges to come to him/her so that he wins through challenges, but also no one will stop challenges to come him/her. Challenges come randomly to anyone but no one can win challenges randomly, it is through working hard and thinking big. If you can't win from challenges, no success you can reach at all. All challenges are from natural environment and ourselves, they can come whenever we want or not, but do fail to resist to come with success, don't fail to manage your project, take challenges like it was sunny by the day and it rains at night. Thinking big will give a way to succeed in challenges. Do not fear challenges but welcome them because you are ready to fight against challenges. Plan in mind that you will meet challenges before challenges notify you that they are coming and remember that sometimes challenges come without notification. With this regard, we should always be ready to win despite difficult conditions we can ever face. We can be proud if you succeed through challenges and difficult, you can be proud and good example to others due to success comes from challenges. You cannot clean your clothes without soap, if you have used a soap for your clothes to be clean, you are really sure that the clothe is clean due to the use of soap. You will be sure that your success is ever lasts due to challenges. Untested success is not success at all, and is a good short cut to fails. If anyone wants to reach success easily, he/she needs sometimes to think on future fails, and if we fear tests it means who we are. If you have knowledge, do not fear people to challenges you, and in challenges we build our confidence but also add something important on who we are. Whoever you are, whatever you have, wherever you are accept reality of challenges in what you are doing, but don't accept challenges to fail you but accept challenges to a successful person. Succeed in all corner of life, and don't mind if you faced some fails in you travels, it's all preparing you for future success. You are not a winner because you cannot fail anything, you are a winner because you don't fail trying. Truly people can mock at 
you due to fail, but remember you are yourself, and you will never be anyone among those who can mock and cerebrate your fails. A mind dead person cerebrates fails others but is the one to fail tomorrow. Be you in both fails and success and do not fail to try again, it is through trying that anyone is successful.

\section{Those who experienced blandness of pain understand the taste of success- Dr. Callixte Yadufashije}

If anyone wants to understand pain, think on wounds and remember how painful they are, once the wound is healed, remember how happy you have been. It's not difficult to understand how happy you can be when you sort out from your difficulties with positive situation. Take a look in your past and remember how long you have been struggling, and remember when you left the issue positively, how were you? This quote wants to refer to the situation in which people attain their success. Actually, success sometimes is not taken in consideration if you have been attaining it easily. If two people are working on something, those who are in difficult situation will be successful than those who were in good life. a child of a minister cannot be surprised by his/her bachelor's completion because of life he/she experienced. It is not a miracle that a child of president flies with a plane. However, people who have been facing difficult life understand how difficult life is than those who experienced simple life. any achievement from dark and difficult situation is valued than those which obtained simply. This means something important in daily lives, achievements are individual, people face different life complication at different levels, what they achieve are due to their life situation. The value of what anyone has achieved is not depend on its quantity or quality, it depends on the way through which you passed in to achieved. It is through this way that people understands the taste of what they have achieved differently. Ten dollars can have the same value as a hundred dollars depending on how you have reached it or how you needed it. However, not success is easy to reach that's why everything achieved has to be given its valued. Even if anyone gets there easily, but the reality of life is there to tell how life is difficult to some people while is easy to others. It is for a great importance to see people who have been in inadequate life making their life possible, this taste is more tasteful than the taste of sugar. From difficulties success is more tasteful compared to success achieved easily. However, no one is wished to enter difficulties for him/her to taste the success, but understanding of success is different through this way of life difficulties. Thus, the principles of life show that no one ios advised to attain any success easily, we have to work hard to reach our success despite different life. we have to work hard to taste our success otherwise success will be tasteless. People who suffered more understand why their success is meaningful compared to those who faced few challenges in their life.

\section{Do not work hard to satisfy people, work hard to fulfill your responsibilities- Dr. Callixte Yadufashije}

Working hard is the key of success in all responsibilities. To reach any step of success requires much effort and investment of time. However, the results of any success should be the response to friends, communities, the country and the world. This context is true in some situations while is not on the other side. It is always good working hard to produce work outcome impacting the community, however, it doesn't matter if you find that the community is not satisfied at the level you think it can be. Each and every one has his/her level of satisfaction and very one has his will but the work should be how it should not what everyone wants. Working under responsibilities is greater than work under pressure of what people expect from you. If responsibilities were followed in clear and appropriate way, there is no doubt of satisfaction of who you serve. Those who will not be satisfied despite maximizing your responsibilities, it will be there side of expecting what you are not supposed to give them. If anyone fails to respect responsibilities due to his own will, this is where permanent loss comes. Number of factors can influence responsibilities failures, but we need to invest our effort in what we are doing for us to report clear outcomes of what we are doing. Satisfy your inner peace by respecting all responsibilities given in your work even if no one can satisfy all people around him. Satisfying surroundings is not an easy task, because people are not uniform in what they expect from anyone, they can change person to person. However, working in justice is a key to satisfaction of your surroundings. In what anyone is doing, trying justice is the beginning of satisfying people around 
him/her. Nothing is better than providing a harvest from your responsibilities, anyone should work hard to come up with positive harvest of his work through respecting his/her responsibilities. To be responsible of something is not measured via appointment letter from the employer, or from your supervisor, anyone should own responsibilities to be successful in what he/she is doing. Some people fail their responsibilities due to working under eyes of people not under their responsibilities. It is always an early fail if someone starts working under anything else and reject responsibilities, later responsibilities will judge you and will rank you accordingly. Nothing better than achieving something great through working under your responsibilities.

\section{Positive answers are sometimes bad as negative answers are sometimes good- Dr. Callixte Yadufashije}

Few percentages of people expect negative answers from what they are requesting, asking or doing. It is also understood that everyone wishes to make better him/herself, that's why predicting negatives responses are not mostly planned by many people. However, in each step of our lives, planning both positive and negative responses can help in one way to another. Planning only positive answers to any plan can lead to some negative effects if anyone understand things in positivity only. Being positive in life is a very good character but is different from predicting positive or negative answer. How do we need to predict negative answers in our lives? Is it that we need negative answers? Is it because positive answers are difficulty to reach? Actually prediction of negative answers helps us to fight against risk of what we are doing. It is always good to plan and wait for positive outcomes for anyone, but also sometimes it happens to face some challenges that lead to negative outcomes, or not reach outcome we wanted at the level we thought it should be. Secondary, if anyone wants a service, note that you will either receive positive or negative response. Negative responses also can sometimes prevent some consequences in number of situations. Negative answers can be given to protect against number of effects from positive responses. To understand this context one example can be given, supposed that your kid is hungry, and the food was diagnosed and test showed that the food is infected, here you will never accept your kind to eat this type of food which can cause a harm to the kid. Other examples can be given to anyone at this case. Planning for positivity is a goal to everyone, and we should always be positive, but to be positive does not mean to be far from negative answers. Despite negative answers, a positive person will be ready to work under negative situation and will succeed in negative situation. If anyone plans for positive answers, he will never be ready to succeed in negative situation at all. Learning from negativity make anyone strong and learn to succeed in all situations. We always wish positive outcomes, but we should learn how we should succeed if negative outcomes reach us. The life we live in is not a straight line, that this why planning two sides is important for mankind. None is created for him/her to fail but also no one is created to be out of negativity. If positive outcome is planned, we fight against negativity but sometimes negativity lead to fails of what we are planning, but don't meet negative outcomes for you to fail but to learn new strategies of solving a problem. Negative answers are around us, they really fight against us sometimes, but also protect us in other situations, and also make us strong. Positive answers are always good, they determine how hard we work, but also negatives are part of life. such as negatives in what we ask from others, such as negatives in what we are doing for life, they are all important to train us. Our predictions should not base only on positive outcomes or answers, it should also predict negative answers and learn how to succeed in number of challenges.

\section{We learn much of science to have knowledge, but we need to learn much of ourselves to be wise- Dr. Callixte Yadufashije}

We mostly invest our time and effort to learn much in sciences to have enough knowledge in a particular subject that will support our lives in the world. Parents send their children in different schools, and those with high capital send their children in high ranked schools to prepare them for the market of employment and other different competitions. Struggling for schools is all about knowledge search, and knowledge is important for us to live. Knowledge is acquired differently among people, and they are different types of knowledge required for a human to be skillful for people and be competitive. After completing any school 
level, mostly they give you a certificate, a degree showing that you have certain capacity to do something and then you go at the market for jobs, for competition and other source of income and the circle continue this way. However, it is amazing and funny, if I can know chemistry, Biology, Mathematics, Physics, geography and other sciences when I do not know myself, when I do not know the community I live with, when I do not know what is happening around that common to life. knowing yourself is a step to success and is a good way to life. Most of us do not know who we are that is why we sometimes face problems that we have participated in ourselves. You can ask yourself the following questions: who am I? who do I aspire to be? From which procedure I can pass through for me to be who I aspire to be? What will be the outcome for what I aspire to be both on me and the community? These are questions that are important for us to be wise. A wise person thinks broadly not limited somewhere. To who you are is the first step leading to self-identification among others. Self-identification shows you what you capable of and what you need from others. Self-identification leads to community identification, and lead to social identification and beyond society. If you are not self-identified, you are no longer succeed in your plans, you are no longer create uniqueness and you are no longer be free in your mind. To self-identify requires to accept reality of who you are. If you self-identify without accepting reality of who you are, you totally destroy yourself and no success at all. If you do not self-identify correctly at the beginning, do not wait to be who you aspire to be in the future because you have the wrong beginning. After self-identification, you will know where you are and where you want to be. Through this, it will be easy to know which procedure you need to follow to reach on your plans. You will not face difficulties that interfere your journey because you planned it in wise way. You will easily know supporters you need, and when each one is needed to avoid mixing things. By then, you need to think broadly, we are in environment, we are surrounded by people, animals, plants, and small livings. We always need to take in consideration our environment because, everything we want can affect the environment especially humans. If you think on yourself, you mind will be limited to yourself, and will not grow in terms thinking broadly. You know the effort invested in problem solving, depends on how big problem is, so if you think on yourself, the effort you will need to invest will be proportionally to yourself. If you self-identified, you know why you need others, and you know why they need you. If you are sure that you need others, there is no longer you offer a bad thing to them. Knowing yourself is the beginning of wisdom, and wisdom is itself good living. Any knowledge from science is nothing if the holder is out of reality we discussed about in this quotes. A self-identified person will be a source of good change in the community, and will offer what community needs from him. A self-identified person knows is that he/she will be alive for sometimes and later will die, then he/she will strive to leave peace, and good heritage to the community around him. A good heritage to community will be a good heritage to yours or your family. A wise person knows that if even if he is satisfied enough and no need to request a big help from others, but his/her children, family members will need others is some situation. There is no justification of mistreating others in life because we live through them. We need to know ourselves and live long in reality of the world.

\section{Many people fail not because of capacity but because of determination- Dr. Callixte Yadufashije}

Many people are engaged in number of activities because they are capacitated to do so. If someone is capacitated to do something why does he/she fails to make it? if you have capacity to do something where does fails come from? Capacity is one thing but also determination is another thing on the other side. Capacity shows that you have everything to do something and determination explains that you are in a good position to make it. Capacity is may be knowledge, experience, or degree earned during school education. You can also be given people to assist you for you to have enough effort to reach your goals. Amazingly, we find people failing and wonder why? It's matter of determination in normal circumstances. Planning is one thing but also implementation is the second step which is important for us to avoid fails. Having a project and implement it is important but also sustainability of what the project achieved is something expensive that we need to consider in our lives. Determination will tell you all about plan and its implementation. For example, a determined employer will not disvalue his/her employees, he/she is sure that employees are working for his company and without them the company cannot work. A determined head of a family will not disvalue a house maid; he/she knows that the housemaid takes care of children and cook their food 
at his/her absences. Determination will tell you that you are not authorized to go for bar to drink during working hours. Many people fail due to determination, they think that having capacity is enough but that's not how things are. Determination is an important element of time. Investing our time in what we are doing is also a part of success. Failure comes from the absence of determination. do not always be the boss to who you need to supervise be humble for them to be free and invest their ideas and innovate with you. Do not close your eyes for you to expel those with difficulties at your work, an employee works well when with a good life. self-determination will give you a good team to work with and avoiding sometimes these teams with no sense will important for our success. Social living can be a barrier to success that is why we need to know limitations in detail social livings. Determination is judge to the level of effort invested to reach success. Bad determination will not take a long time to fail anyone who worked under this darkness despite having enough capacity of doing what is responsible for. Determination is a good tool to support our success, and each person should ask him/herself questions related to determination before the beginning of every activities or work. If I am capacitated to something, am I determined to make? If not, what do I need? By this way there is no long experience failure in what any one plans to do.

\section{Simplicity is not always a measure of weakness but it's always a measure of validity- Dr. Callixte Yadufashije}

Simplicity is a quality of making things easy to understand or to be done. Others can provide definition the way they wish to understand. This quote was written to show how people should live in their daily lives. We are not alive to make life difficult for others, we are there to make life possible for others. We are changers of life to others and this should be done in a simplicity manner. In what we are doing we need .to be simple for others to access us. Actually, in social living, we are not the same in terms of occupation, families, education, color of skin, and others, however, no one is authorized by the law to disvalue another due to these conditions. If I have a good job that pays me much, why do I need to disvalue those with low salary than mine? If am highly educated, why do I need to disvalue those with low level of education? If I am to provide a service, why do I need to delay them when is their right and my is responsibility to provide it? all of these conditions should be understood in a good principle of simplicity. No one will be weak due to simplicity to others, and no one will be strong because of complicating things to others. Most people lie themselves that complicating things will make them respected and take simplicity as a measure of how weak someone is, but this is not really true. We need to be peace to others, we need to solutions of others, we need to be ways of good life to others and these do not require many things except simplicity. The value of ourselves and that of others will justify our validity. Nothing is better than having appreciation from who you served that you have been a simple person to him to provide services he/she wanted from you. Simplicity should be well understood, it is not way of simplifying things that were difficult to reach, it is not like this, simplicity of someone is way of being simple for someone who needs you, to provide guidance or services he/she needs to reach to solution of what he/she need. Simplicity is measure of validity for how you have been serving, for how you have been working and for how you have been taking everyone who needed you. You will not be weak due to being simple for people who need you, but you will be a popular person. Simplicity will convince people that you are an important person to their lives and they will consider you and this consideration will ever last from you and generation to generations. Simplicity in what you do will be an indicator that you have been important to others, and will be a good heritage to your descendants. Be proud of being an important person through simplicity and let your family be considered through what you did for others. Be simple not to be week but for better the world and this will build the confidence of those who are still low in their lives.

\section{Wise people are always curious to know the way towards their dreams, but fake people always waste their time negatively criticizing what others are doing- Dr. Callixte Yadufashije}

Criticism is an act of criticizing a certain situation. Critics are always done to find better solution, to see how things should be done, but also sometimes done when someone has done things in inappropriate 
manner. Criticizing itself is not a problem and doesn't matter and depends on why you are criticizing. By criticizing we should take in consideration the following: why do we criticize? What do we learn from critics? What is the outcome of critics? Some of us criticize to find a good outcome in what we are doing and this is good really in life. however, they are people who are there just to criticize only in negative ways on what others are doing, whether they are good or bad without giving their interventions or suggestions. Friendly critics are important for better improvement of life, but if critics come to show how someone fail and cerebrate how he/ she did not reach what he/she wanted, this where things become useless. There are some people who like criticizing others in a negative way to permanently disvalue what they are doing, and to inform the public that the person has no quality at all, and these are known as fake people. they are fake because they are somewhere for only destroying not for solidarity. They are fake because they want everything good to be for them and not others. They waste their time controlling and evaluating what is not in their responsibilities, they waste their time marking works of others, they make busy themselves for nothing. They are weak to compete through knowledge and experience but they are strong to mean nothing and no sense. They always waste their time on this and no longer work for their achievement and always find themselves late in what they were supposed to do. Wise people do not mind for those who are negatively criticizing them, they are sure for what they are doing and do not wish to hear any word from blind people. wise people work hard and use their time as their important investment. Wise people work under their dreams day and night and negative critics for him/her mean nothing to what they want to achieve. If you waste your time to criticize negatively what anyone is doing, keep in mind that you are wasting your time on him/ her but he/she is using his/her time to reach his/her dreams. He will later become what he/she has been doing, you will regret for time wasted. The community will recognize his/her effort, but no one will remember your negative critics. Negative critics for destroying purpose kill the criticizer and harvest nothing from them, we could not be like people without direction, our time is expensive and is a good investment that we should use to reach where we want to destroy others. If you criticize others to destroy them, you will later destroy yourself.

\section{If life is not a straight line, fail doesn't matter. What matters is weakness to continue your life trajectory- Dr. Callixte Yadufashije}

No one has reached something straightly. The life we live in is not straight. The live we live in contains tragedies that really fight with us until we die. It can be good to everyone if he easily gets what he/she wants but the reality shows that it is not possible to reach what we want in a direct way; thus we should adapt the condition of reality. Do not think that is the end of life because you have failed to reach want you wanted, this is the reality of the world. If you have done what you have supposed to do, do not condemn yourself that you did nothing at all. We live in life of trials and we should always try. Some of us do not be ready to resist for failure, but for any good background, no one has reached there without facing challenges. Failure doesn't matter if you have done well and no fail reaching the outcome you wanted. What you do is to revise the way and procedure, or you can try the second manner you think is the good way to reach your result. Do not limit yourself due to failure try and try again until you reach your way. Failure does not matter what matters is stopping your life trials. If you stop your life trials, you will permanently fail. Avoid stopping life trials to prevent permanent failure. Number of people lose their effort if they experience failure and no longer interested on what they have been doing. Some of us if experienced failure we create destine of life by saying that this is God who planned it and nothing I can do. The greatest fail I have ever seen is the creation of destine in what you are doing, avoid such understanding as it brings barriers to your success. You are your own destine, the way you work justify what your destine hide. The way you think shows what your destine will produce in the future. failure is a part of life but is not our choice. If failure comes, resist on it and work hard for brilliant future. not failure is for life, not failure is for heritage, failure should be the way to learn a new fact, and progress for better success. Nothing better than succeeding under failing conditions. Be you and do not change your mind due to fail. Be you in all situation continue your life struggle. Continue working until you reach on your dreams, do not cease your effort because of failure, continue investing your time and effort to succeed. Nothing and no one will fail you if you do not fail yourself. Failing yourself is not doing anything else, it is stopping your life trials for better living. 


\section{Achievements are not only measured through high positions occupied by an individual but also through his/her inspiration to the community around him/her- Dr. Callixte Yadufashije}

Measuring achievements is always done in our contract performance but also personally measure achievements due to the life objectives we have. However, many people measure their achievements by looking only at their high positions but they also need to measure also how the community was inspired by your work. Achievements themselves speak to people that you have achieved much, but most of us do not refer to how the work and achievements have changed lives of friends and community. They are no achievements at all if they only reflect your own interest. What you did for people in what you have achieved is the justification that you have achieved important things in life. if your achievements are for your own interest, this means that you have achieved nothing. Having high positions in companies, institutions and organizations is important but if one does not use these opportunities to serve others, there will be no chance to explain achievement achieved. Achievements do not mean sitting in a good office and people come and wait you for long time, a good proof of achievements is contribution provided during what you have been doing. Through working to others, through being productive for others achievements, you will justify what you have achieved. Some people are happy for what they have achieved through educational levels, positions occupied, but once asked how many people they helped and reach where they are through then, they respond nothing, so if you respond nothing to who you helped in what you have achieved, your achievements have no justification. You have achieved what you have through others, you can also inspire the community around you, you should let them know what you have achieved. Every one wish to achieve but also the way we want to achieve; it is also the way that others wish to achieve. If you have achieved, it is good and continue winning on your side and help others to win. Helping others to win is a great thing that anyone will never regret, your achievements will be for life if shared with others. If anyone hide his/ her achievements, he/she will know that he/she has achieved but no one will cite his/her achievements. Let people cite you, don't cite yourself. To be cited by others justify your achievements and how they impacted the community around you. If what you have achieved did nothing in the community, you have no one to tell what you have achieved because you will be asked the impact of what you have achieved. Good achievements are achievements that serve people and change their lives in some situations.

\section{If value to others can't depend on humanity, it should depend on dependent life that every human being lives in- Dr. Callixte Yadufashije}

Humans depends from each other. No one has grown for himself without intervention of others. We born and begin life journey from zero years. We grow in hands of our mums and take care of us till we become mature and produce our own children. Nothing you can give your parent for what they have done for you, but at least you can give value to them. Remember that your life needs are many, and they are what your parents cannot give you, they should come from other people either you know or not. Since a human being born and grow, he/she passes through different life stages, and people supported him/her to reach any stage of life. remember for example the time of your primary schooling, the teacher strove to find a good content to give you, for you to be a skillful person, till you become a skillful person even more than him. Remember your long travels walking and when thirsty you went in one family randomly to ask for water, may be they did not know you, but they gave you water and continued your trip. Remember the time you did something good, people used their time and come to say congratulations to you, no one you have paid. Someone started a company and employ you and other thing related to dependent life. we live in dependent life, we depend from each other whether you accept or not, it is the reality of the world. You can pay you money for a flight, it is understood that you invested much for your flight, but remember the effort used by the pilot to protect your life do that you reach where you are going safely. This dependent life does not authorize us to disvalue any human being, even sometime animals and plants. A human being is important for your life in one to another, they help you in random way that you have never planned. We should value a human being because we are humans. If you fail to value a human being, you have no value at all. It is a 
human being who made you who you are, it is a human being who planned where to passed through to reach where you are today, so these doctrine of dependence between humans should be understood better life in the world. Some of us cannot understand how a kind of three years is important but remember the way you call a kid to give you a cup from cupboard. Housemaid do everything at home and you come when everything is fine, and if you think a housemaid is not important, then, why do you bring him/her? This context explain the principles of dependence and how how no one can do everything for himself. We need from each other, that is why we need to value every human being whether is poor or rich, he/she will play his/her role at his/her level. If you are sure that you will need people, you should even take note that they are for great value. And if you now understand that you depend on others, let them depend on you, do not chase out anyone due to how you identified him/her. To be a human only is enough for anyone to have role in the community. An element of any community has a value to bring a good change if well treat by the community. However, in our community, most of people are mistreated, and this mistreatment make them to consider themselves as they are nothing in the community. If people are given their value, truly, they will be productive in the community. However, if these people are not well treated, it will be a big loss to the community. Those who think are productive in the community should not always try to show those who we think are low that they are nothing and cannot produce something to the community. Let us give a value to our community to build value for ourselves and the same community will take care of us. A human being is important for anyone, and nothing anyone can achieve with humans' participation that is why they should be given their value.

\section{Truth doesn't always mean reality but reality is always a proof of truth- Dr. Callixte Yadufashije}

Most of us confuse what reality is and what truth is. Reality reflects the state of things as they actually exist, truth is the quality of being true. In the life we live in we always ask if what someone is speaking is true or false, how do we justify this? We justify whether something is true or false through reality. Sometimes, truth is discussed by a group of people and sometimes this is taken as truth due to what have been discussed, reality is not discussed, it is an opposite to idealistic. For example, no one who believe in reality who can be in holy spirit, there is no reality showing the existence of holy spirit. Holy spirit is idealistic no one knows it and no one has seen it to confirm its reality. We sometimes accept truth but when you evaluate its reality, you find that there is no reality at all. We need to always verify truth where necessary, reality doesn't change, the way it is, it remain like that. Sometimes people edit truth due to what they want and create its reality. Anyone will fall down if he lies reality of truth. Reality is there to verify truth discussed, however the high percentage of people do not verify reality of what they do. Being in touch with reality is the greatest chance of success at all. People fear reality because sometimes it refuses what they believe as their truth. Reality cannot be edited, it is there as it is, it refers existence. Truth is true if reality confirms it, and reality doesn't confirm truth, this truth is edited. I can say that I believe that God gives children for couples, but no woman who has not met a man and have children. The reality of having children that a woman and man meet make children. Reality will open your mind; reality will tell you who you are reality will make peace in your mind. Created truth are confused cannot make freedom of mind. Like truth of life after death, this concept was created by Christians to show people that if you can die, you will resurrect at the end of the world. In reality among people who died, none has come back to tell us about this belief. Life with reality will not lead to consequences, but edited truth will lead to consequences including poverty of level of thinking. Better to face difficulties of reality than facing consequences of edited truth.

\section{Planning before dreaming is like Present without future- Dr. Callixte Yadufashije}

What we plan should be based on what our projection showed us. Our dreams should support our plan. Generally, you do not plan to dream, but you dream and plan. Having a vision before planning will support anyone to be successful. What you have in mind, what you aspire to be, will tell you which plan you need to achieve your vision. Your dream is the same as your vision, vision is not a random thing, it is not a miracle, it 
should be based on personal focus. The mind should be broad through thinking big, and thinking big is a way of have a big plan and achieved all about your plan. Most of people work without direction. Working without direction achieve nothing, and help someone to waste the time. This quote was written to remind people working with objectives, and focus. What you have had in your dreams, are what you plan to do. Having no vision means having no plan. Whatever anyone plans, should be based on his vision or dreams. A student should know why he/she is doing bachelor's degree in a certain field of study, and this will help him/her to know what he/she will do with the degree. The response should be; I am studying this program for me to be an entrepreneur with enough knowledge. Nothing is done randomly for those with clear dreams or vision, if the vision is well defined, planning will be easy for anyone because he/she knows where he/she is and where he/she is going. Anyone will reach nowhere is he/she plan without direction and longer his/ her success play a role. Having a dream has no relation of your current status, it has no relation with your current friends, it has no relation with how big your family is, it has relation with reality of possibilities. If people had dreams and achieved them, why not you and why not anyone else. Having a dreams is not enough, working for your dream to come true is a big stage that require the dreamer to pay attention and be careful for each stage of his/her plan. Dreams are there to support your plan; dreams are guidelines for you to be a successful person. Planning a difficult step and can lead to the fail of dreams if the planner does not plan well. The owner of dreams, is the same person who plan the through which dreams are achieved and no one else to do this in his/her behalf. Any plan will reach nowhere if it has no objective. Having clear objective will be supported by having a clear goal. Believing in our capacity should be in mankind mind and it is through this confidence that we succeed. We mostly call people to advice in what we are doing and this doesn't matter, however, be you before calling anyone to advice you in what you are planning to do. Be yourself before believing any advice, the person can fail to advice you because he/she was not with you in your dreams and plans, that's why you need to be yourself before receiving supports from surroundings. Let us have dreams that will come through clear plan. Having a dream and achieve it is the creator of inner peace at all. There is no big difference between living without dreams and dying. Better to die than living without dreams. If I live without a dream, I consider myself dead.

\section{For a long time, I thought life as a circle but is not, life is unshaped and seems to be like a mathematical parametric equation with infinity values of parameters- Dr. Callixte Yadufashije}

Life we live in has no formula. Life is complex due to its variability from birth to death. Death also is a part of life. a human born, cooperate with his friends of the same generation, in later life, you separate and create new friends and this is not choice in many cases. The way you thought people is not the way you have seen them, the way you thought your status, you find later is not the way you are, who you think will be with high status, they sometimes be with low status and other examples. Life can create and shape the way you are, changes in life corresponds to changes of environment. Environmental changes influence the change of life. this quote was written to remind people that they should respect every human being because life can change the way we did not predict. Life has various parameters, a parametric equation has parameters that can have different values, these values can explain well different ways of how life changes in many situations. No one was born to be constant, things can change in life and reality can show that life changes and things change to anyone in the world. We are ourselves changers of life, we are ourselves solvers of parametric equations that we are creating. Mostly people consider life as a circle, but sometimes no justification of how this shape is. Life has different shape which make it unshaped. Life has a shape like of the graph representing a parametric equation. Shaping life will depend on the value of life parameter, it will be may be circle shaped, ellipse shaped, curve shaped accordingly. The value of life parameters will be the shape of an individual who is living any form of life. however, the way that the value of life parameters changes, the same way the shape of life change. Some people experience good life today and you sometimes find them in suffered life in certain period of time. You find people in suffered life today, and find them in good life in their future times. These realities are known by every human being in the world and is good lesson for wise people. it is amazing things to find your life changing positively and is a sorrow to find your 
life changing negatively. If you are satisfied with today, do not forget that you will need others in the future. it is a big homework to learn how we can make life better than we make it bad, but if you have something today, you need to share with others for future support in your life. we can learn to shape good life if life is unshaped. To say that life is unshaped means that it has various shapes, and it is our responsibilities to choose good shapes of life we wish to live in. shaping good shapes of life is through solidarity.

\section{Do not always use your struggles to show your pain, use your struggles to be a successful person- Dr. Callixte Yadufashije}

If you have not struggled, you will not explain about struggles. Struggles you are facing today, do not mean everlasting struggles in your life. you are facing struggles of life but you are not created to a struggler for life. most of people do not resist for their struggles, they get weak due to struggles and sometimes talk to people who will not bring solutions to them. Talking to people during struggles, telling them that you are suffering with no purpose means nothing and has no sense. Our struggles should be a class to learn other concepts of life. if anyone is facing struggles, it doesn't mean to waste his/her time telling everyone about his/her sufferings. Facing struggles is a good time to think how you can get out from sufferings and struggles to be a successful person. Only those with problems wait solutions to their problems, you don't have a problem, you cannot learn how solutions come. In struggles, learn how to have solutions of struggles instead of using your most of time telling people how impossible life is and how struggling is bad to you. Exercise to yourself in what you are facing and avoid useless people to come in your life and profit your weakness due to struggles. Clearly, useless people will come in your life but if you allow them, they will put you down and no solutions will come from them. To find solutions in your struggles, avoid useless people, and find wise people who faced challenges, and who knows about challenges, but who are ready to help you. Useless people will destroy your name, and sometimes will delay solutions of your struggles to come. Time of struggling is not a time of destroying your name due to problems, is time to learn and reach a successful solution of problems. To use our struggles to be successful means something important, in our struggles we learn to work hard, we learn to save our time and also we take attention in what we are doing so that we don't increase sufferings in the time of struggling. However, if struggles increase, do not worry, and don't lose confidence, as losing confidence leads to permanent fail. Believe that struggles will end and cry to show people that you are suffering, they also have their problems. Be wise in your struggle and find solutions in all corners. Be confident in your struggles to avoid people destroying you and make yourself a valuable person. Ask advice from some important people and think twice before implementing what they are telling you. Struggle is a good trainer that trains how success is reached. Don't profit struggles to destroy yourself, use your struggles to learn how to work hard and be successful.

\section{A human being is a life hunter, and should hunt life all over the world. Thus, being white, black, tall, short or anything else doesn't matter. Do not be white, black, tall, short or anything else for your dreams to come true, but be wise and consider every one like your future investment- Dr. Callixte Yadufashije}

Life is hunted. We do not get life randomly, we don't sleep and find good things coming to us and this condition allows to enter hunt of life. we need to hunt life in good manner and without closing ways of others who hunt life. hunting life is responsibilities of everyone but also making peace for others who search for life is important. We hunt life for us to survive. In what we are searching they are things we need to keep in mind in terms creating the inner peace and external peace for us to keep safe for ourselves but also surroundings. Some people create opportunities of themselves by destroying the chance of others. Some people use who they are, their status, continent where they come from, families, countries for their dreams to come true, but this is not a wise way of working for dreams. Anything we reach is through others, we do not need to destroy chances of others for our dreams to come true, they are our future investment. We need to create opportunities of ourselves, by keeping in mind that they should benefits others as they are our future investments. Most of us do not think on others when working, if someone is poor, nothing 
can be given to him/her, people are interested on who they can receive their benefits, but this is not a wise way of leaving. You do not need to be black for your dreams to come true, you do not to be white for your dreams to come true, you do not need to be anywhere in the world for your dreams to come true, but you need wisdom for your dreams to come true. Any skin color you have doesn't matter, any country you come from doesn't matter, any family you come from doesn't matter, any skin color you have doesn't matter, what is necessary is to apply principles of reality in what anyone is doing. The important thing is to avoid stunting of your mind, train your brain to keep important things and accept principles of reality. The brain should always work and think clearly on your dreams. All mentioned things do not matter for your dreams to come true, but your mind matters. Nothing is for nothing, the mind should be in touch with reality for anyone to have the positive impacts from his/her dreams. Changing mind is more difficult than changing skin color, changing mind is more difficult than having a reach family, changing mind is more difficult than marrying a beautiful wife. Changing mind for reality is the start of wisdom for an individual and no longer wish to be anyone for his/her dreams to be true, he/she will only wish to be him/herself and will understand how everyone is a contributor of his/her dreams.

\section{Success is not about amount of money that someone's has, it's about achieving dreams- Dr. Callixte Yadufashije}

Confusion of what people call success has been for long. People confusion richness with success, people confuse wealth with success and people confuse amount money that someone can have with success. However, having money can be an outcome of success but all depends on dreams every have had. People have dreams and locate in different places of the globe, what I need is not what some else needs, the amount of money I have should not be compared with what anyone has, because we don't have the same dreams and what we need are different. If I have 100 dollars to buy a bicycle as a dream, I am successful. Amount of money that anyone has, is not his/her measure of success, it will all depend on what you dreamt to be. Most people who are known to use money as they proof of success, think that if someone has few money, they consider him/her to be a failer person but this is not true. Everyone has dreams and no one dreams in behalf of another person, we dream differently and we are not supposed to have the same achievements and we are not supposed to be compared using amount money we have. Having money is important and we really need money for us to live with good health, but the amount money we have should not measure of success. Success is individual, it is not a common thing to compare between us. If you had a dream to buy a a bicycle and bought it, it is achievement of your dream, if you have had a dream to buy a car and achieve it, it is success of your dreams, if you have had a dream to complete high school, and completed, it is success, and you have had a dream to complete university and achieved it, it is success and depends on individual dreams. Measuring whether someone has achieved responsibilities at his work in company or institution, we look what every employee was supposed to do to see if he/she has succeeded on failed. If you earn 200 dollars a month, your savings should be calculated basing on 200 dollars not 1000 dollars earned by your coworkers. Anyone should avoid comparing money income from anyone to his money income to see his/ her level of success. My dreams my success, your dreams, your success and his dreams, his success. I dream to be is different from I dream to have money like of someone else. We have different dreams, and no need to compare yourself with anyone in terms of money or anything else. Work for your dreams compare money you have with your needs not with what anyone has. You are successful not because you are a millionaire but because you have reached success of what you dreamt to be and have.

\section{It's always difficult to dig gold underground but it's a must to change History- Dr. Callixte Yadufashije}

Digging gold is not something easy to anyone. Digging a gold requires to enter underground by digging until you reach where gold is, and take it. if you are not an expert while digging death is sometimes possible. Digging gold should be possible in difficult ways and if experts need, they can come and help you because gold has a big value in our lives. We always strive for better life, we sleep few hours for better life, we go in schools for better life, we travel distances for better life and everyone has his/her own ways to dig. To have 
good life is a gold we always fight for. It is not randomly that good life comes, it is through sweating and working hard for your life to be the way you want. If you wish to a gold to others, it will not be cheap for you to achieve, it has difficult eligibilities. Even if eligibilities are not really easy, but it is possible to be done. To be who you want to be should be reached by investing much effort, by investing your mind and by investing your time. We do not need to tolerate anything that want to fail us reaching the gold that we want, we do not need to tolerate anything that wants to delay us, we need to concentrate on what we are doing. To reach the gold, many circumstances will come to fail you and nothing else you will need to do except fighting with them until you reach the gold. Before reaching the gold, you dig number of shells of the soil and are hard to be dug, and having enough materials is important. If you are at the field to dig gold, be careful to have all materials you need so that you reach the gold. Don't worry for those who died because digging, strive to make differences. Make sure that you know the value of who you want to be, and if what you want to be could be compared like gold, it will not be easy to reach without sweats of blood sometimes. Don't mind on how tired you are, focus on how what you want is expensive. Reaching gold level should be understood, having a distinctive achievement should not be something to reach in an easy way. Gold is costly and if you have, it means that you are not cheap, planning all costs for buying gold will take time but gold will be reached. We mostly suffer for us to have what we wish and want to be, and this doesn't matter, what matters is stopping the work reading to the gold we want. If you need people to cite you, you should have published journal article, books, book chapters and other papers that people will read and cite you, and this will cost much of brain, money and time. No one will reach gold easily, we should work hard to reach gold we want, it doesn't matter for the cost, because the cost is proportionally with the bought product. The big concern is

\section{Education is not a way of making life easier, it's a way of making life possible- Dr. Callixte Yadufashije}

School education has been a priority for parent to prepare vision of their children and families. It is always good to take our children in schools for them to have knowledge and skills of their choices. There are number of reasons of taking our children in schools or ourselves go at schools. At schools you learn what people need, you learn cooperation and collaborations, you learn culture, you learn behaviors of others, you learn experiences from others, you learn how problems should be solved, you learn to transfer skills in practice for you to survive and maintain your life on the planet. The best of school education is based on what are listed above. Most of us have been struggling for education for good health and plan for bright future, and after completing, some of us have reached success they wanted, others have reached some of their dreams and others reached nothing or reached thing that are not related to what they have studied. Education is not there to make a simple life as most of people think, it is not a short cut to reach an easy life, it is like other different ways that support us to reach your dreams, it is like other ways of planning your future through acquired skills. Because you are educated, it doesn't mean that you have done what you are supposed to do. Education becomes a tool you can use to reach your goals. Education is not only having a paper confirming that you have completed a certain degree, it is also being ready to explain what you have done, share them, and implement what you have studied. Some people are interested to know whether you have degree than knowing if you are ready to implement and do things well. Education is a key for anyone to have a broad mind and broad mind support you to positively think. If education did not change my mind, it seems I have lost the time. Having knowledge is one thing but also having broad mind to use knowledge is the second think. An educated person is only someone who can explain science in a good way, having reality also is more than anything else. Education can lead to wisdom and if we become wise, our minds become free, and discover what knowledge mean and how should be applied. Only wise people knows what knowledge means and what knowledge will do for them. Educated people should keep in mind that after completing a program of study, knowledge continues to be increased in different ways. Awarded papers are not a tool you use to explain what you know; it is a tool that shows that you have completed a program of study. Be educated in mind not only in papers. Education in mind is better than education of papers. Education is good choice leading good life and healthy mind but what anyone needs to understand is that education will never make life easy, but it will create possibilities for you to reach your goals and dreams. Some of educated people fail not because they don't have papers showing that they are educated 
but because they don't know what education mean and what education will do for them. Education is an exposure for you to be exposed to number of opportunity but you should learn to use your chance, and show that you are educated. Education should be the key point to reach where we we want to go if we use all chances exposed to us. Education is a good way to create opportunities, educated person is the one to use chances that come to him/her. Education will never make life easy but it will create opportunities.

\section{If you want successful life through others, let them first be successful through you- Dr. Callixte Yadufashije}

We all live in depend life, whether accept or not, it is the reality. Selfishness is a big barrier for us to reach successful life. It is always difficult to think what I can do for friends, before thinking what friends can do for me. It is amazing to think what to do for others to have good life before thinking what I can do for myself to have good life. but if we can think wisely, what have you done for people to do the same for you? What did you contribute for others and what do you wait from them? If you did nothing to others, why are you expecting what they will do for you? Better to work for others before expecting what they will give us. Successful is through our surroundings and surroundings will tell you the progress of what you are doing. If you always fetch water from the lake or the well, you will always keep and take care of the well as a way of taking care of yourself. Most of us confuse the way we live, and we think if we are personally satisfied, we done and is enough. If you depend on people who are suffering, you will later suffer with them. If you don't every possible for your friends to be safe, you will later suffer from unsafety situation. Building safety to others is the good success at all as they will do the same to you in normal circumstances. We are tasked to make a good and favorable environment for good health and people are the first component of environment. We need to build others for us to be safe, if others are safe, you will be safe with them. If you want something good from others, you need first to something good to them. If you start doing something good from others, you already reached the first point of successful life. If you have discovered that what you need is also what also others need, you are at the key point of become wise at all. The mind should be free to have free thinking and this will no longer hide your inner. Expecting from others is good, but keep in mind that others are expecting from you. Do everything for you to be important for others, try to be the provider for others, and strive to be the contributor than being a receiver. It doesn't matter on how the level of your capacity to support others is, do your best and keep in mind that what you are doing will later come back to you. Doing something great to others should be in our minds if we want to succeed in our plans. The late of expecting from other, should be equal to the late of offering or giving to others, and out this, there is no success from other at all. Sometimes is better even to plan offering much than what you will receive from others. If we agree that we succeed through others, let us make them succeed in their plan, for us to succeed from them.

\section{Those who see others in the mirror of weakness are the weakest- Dr. Callixte Yadufashije}

To be weak or strong in something is for every mankind. No one is strong in everything, and no one is weak in everything, everyone has what he/she is capable of. Some of us reject people that we think are weak and this is not good since we find that anyone can be weak or strong in something. Taking time to categorize people with categorizing yourself first, it is the enemy of intellectual growth. If no one is strong at all, no one also is weak at all. When it comes to choices, everyone has his own choice and choice help you to be either strong or weak. We couldn't sit and take time to classify people for discrimination purpose, we could do it for us to support those we think are weak. Anyone will fail to learn from others if he/she thinks they are weak enough to reject them. Learning is a process and for everyone who wants to learn much from the world. Rejecting people you think are weak is the purpose of ignorance. The way that we manage people shows how wise we are, and learning how people have become weak is important for you to avoid facing the same consequences. The strongest person is the one who make others strong not the one who reject weak ones. Those we think are weak will cite our names if we make their dreams to be true, don't fail learning from someone, if himself learned from you. Any loss in learning is the beginning of ignorance at all. if you are strong, there is a reason why you are strong, you should keep grow and support others for you to continue 
being strong. Someone can be weak in dancing but strong in singing, you can be weak in mathematics, but strong in chemistry, you can be weak in speaking but strong writing. The strong person is the one who is wise to discover what the people he/she thinks are weak are capable of. Sometimes they don't know that there is what they do due to different factors such as internal or external factors. If we continue rejecting people we think are weak after failing discovering what they are capable of, we can consider ourselves the weakest. Failing discovering what they are capable of can be due to ignoring them, thinking that they have nothing and other different factors. We need to confirm weakness for anyone if we find that he/she is weak at all and this cannot happen in normal conditions of life. To be called weak means nothing if you can sort out from weakness, and sorting out from weakness is based on knowing what you want and how you want to reach what you want. The way you become who you are could be the success for others as they will learn much from your success, don't reject them and don't create barriers for people to reach you. The way you create barrier for people you think are weak to reach you, it is the same way you create barrier to reach people. if you are not available for people, you will later find that they are not available for you. Better to strong for others success and weakness is not a choice to anyone, let us support from each other for better living.

\section{In Life, we should learn from others, but we should not copy their lives- Dr. Callixte Yadufashije}

Learning from others is different from copying their lives. We really need to learn from successful people but we do not need to copy what they have done. Why do we need to copy what others have done? It should be understood, copying what others have done is an enemy of success, since you don't know the level of his resources, vision, and funding, you cannot copy what he/she has achieved. Remember that you learn from others but sometimes have different dreams and visions in different environment. learning from others in one way to another, could be the way to reach your dreams, however, don't use much of time to copy what others have done, learn from them and apply them in your way to reach your goals. You couldn't live the life of anyone else, you live your own life, and this principle allow anyone not to copy life of others. Nothing better than reaching things through your dreams, through yourself and through the effort of yourself. We need to learn from ourselves before learning from anyone, and if you learned from yourself, you know who you are and what you are capable of that's why you don't need to copy what anyone have achieved. It doesn't matter on who you are or what you have now, learning is not short process, it is a long process and nothing can be reached without learning. Copying and pasting what others have reached can be a leading cause of failing dreams, since your dreams were not based on copying what others have done. Since people are not in the same conditions, we do not need to think copying what anyone have achieved despite learning from them. Let us know what they have achieved, let us know where they have started from, let us not challenges they have faced, let us know of course mistakes they have done and let us know how they sustain what they have achieved for us to prepare enough. What others have achieved, are from their effort, it is from their sweat, it is from their investment, thus, anyone also needs to invest his effort, his sweat, for him to value what he/she can achieve. We learn to achieve; we don't achieve to learn. Achievement can delay due to learning process, and if learning process ends, and you don't find outcomes of what you have learned, you need to revise your implementation process for you reach your goals. you fail achieving due to copying what others have done, because copying what others have done is directly changing direction of your dreams. Changing direction of your dreams through copying what others have done will delay you enough and will lead to fails of achieving success of your dreams. Let us learn to achieve, let us value the time of learning and without learning no success at all.

\section{Struggling for respect no longer gives you peace, but struggling for peace gives you both respect and peace- Dr. Callixte Yadufashije}

Respect is the good quality for anyone, and sounds good for those who are respected. However, anyone doesn't need to use much energy for people to respect him/her, he/she needs to work hard for the work speaks in his/her behalf. Respect should be because we did something different and impacted people 
including ourselves positively. Struggling for respect itself matters. Why do you strive for respect than working for respect? If you create a type of respect, there is no respect at all. respect shouldn't be something interpreted by ourselves, it should be something interpreted by others that we did well that is why we are respected. Using much of time to know whether you are respected or not is losing respect in some ways. What you are doing will identify you, and will tell you who you are and will tell you how surroundings consider you. Any respect should be based on what we have contributed and how positively affect people, it shouldn't be based on how we want to understand ourselves. We need stabilize environment that we live, creating good air in our environment is our responsibilities and that's why we consider ourselves humans, and if we succeed to stabilize our surroundings, respect we need will come to us abundantly, not us to run after respect. Those who need respect will run after respect, but those who are respected, respect will run after them and through what they did that they are respected. We are tasked to solve problem and make sure that people are safe, and if fail doing this, I don't think we need people to respect us. People struggle for their respect through different ways and really this is a barrier to the inner peace they should have, but if we work and our actions speak, we feel peace and no longer we think on respect us our actions provided respect to us. Let people see how you have achieved much and how you have contributed than you show them how respected you are. What you have done is a proof of respect in everything. We need enough time to work for others, as way of working for ourselves. We need to create a good environment for good life than wasting our time striving for much respect. It doesn't matter on how people will respect you if you have done well in your responsibilities. Time of respect corresponds to what others harvested from us not really through what we think basing on what we want. If you want respect, create peace and respect those you want them to respect you.

\section{Do not do things because are easy to do, do things because are productive to you- Dr. Callixte Yadufashije}

Doing something should not be a random thing. Something should be done because of why? The preference of what anyone can do should not be based on how simple something is, but how important it is. The level of how difficulty things are is different from one person to another. However, anyone could identify him/herself basing on he/she likes to invest his/her effort to reach on what he/she wants. Some people likes things are easy to do or can be reached in simple way even if they don't touch on what they wanted to reach. What we do should be based on what we wish to achieve not how simple things are. It should be an eternal regret if anyone fall in unhappy situation of doing things that are easy than doing things leading to what he/she wished to reach. Easy things lead to easy and simple personality. The way we invest the effort in what we want, shows the level of outcomes we reach. Level of investment justify the level of achievement, if you invest low, you achieve low. Doing things because are easy no longer you get your satisfaction and where satisfaction is absent, there is no achievement at all. long lasting achievement needs a big investments and investment in terms of various things, such as time, effort, knowledge and others. Decision of doing something should not be based on how easy or difficulty it is; it should be based on what you want from what you are doing. Note that most of things requiring much energy are more productive. The way we lead our minds to easy things the same way our minds becomes easy and cheap. The way our minds solve complex problems, the same way it becomes complex and expensive. Nothing can be achieved if anyone can wait things to be easy, waiting things to be easy for anyone to work will cause a regret fail to anyone. It is wasting of the time if you wait things to be easy for you to work, you should learn how to start in various situations. What is necessary is that things are productive to you, not how things will be easy for you to work on them. What we are doing should be a random thing, or something that comes by chance, no chance in life, no random things in life, it's all about plans and influences. However, inner influence is the first thing anyone can sit learn, inner influence should learn how to accommodate external influences to reach a productive thing. Inner influence will tell you to work even in difficult things if things are productive to you or surroundings. Sustainability of the work is due to how investment was, low investments leads to low sustainability and high investment leads to high sustainability. Don't mind on how tired you are if you did things that have a good impact to you or to others. 


\section{Books are silent philosophers, you can explain their philosophy through them and become a philosopher- Dr. Callixte Yadufashije}

Philosophy is more complex than we understanding. Philosophy means love of we wisdom and from this definition everyone could be a philosopher. There many written volume of book across the globe in various libraries, online, and in stores. We mostly lead books for us to have knowledge, or use them for reference purpose. Each book has its own reality depending on the author and interpreters. Having knowledge from books is one things but also there is need to analyze realistic context of the book. To understand realistic context of the book requires much exploration on the book and you should know if your sprit is really in collaboration with the spirit of the book. Book exploration means entering details of the book context and this is done through reading all about the book internally and externally. Doing this, you will be explaining about the book through it, but also the book will create scope of knowledge in you, and different critics will begin in your thought which create wisdom in what you are doing. If you have never read about bible, you cannot ask yourself why bible is useful for you or anyone. Book are there to create knowledge and through existence of what we know we begin wondering, and wondering is the beginning of wisdom. In normal circumstance, you cannot be a writer if you have never read books. You wonder because you know of course various sources of knowledge are there but books are more preferred than any source of knowledge. Reading various books to learn a topic create experience in your inner and this is the meaning of wisdom. If you read books, you better discover that what you don't know also exist and what you know are not the limit of knowledge. Ignorance is source short term thinking and short term thinking is the enemy of wisdom at all. Nothing can be done without knowledge and knowledge has no meaning without wisdom. Learning is a process in our lives and failing to learn is a permanent death of the mind. The way we live are based on knowledge and the way knowledge is translated to what we need is mostly based on wisdom. Knowledge is a tool that wisdom use to make life possible. Wisdom clarify what to do with knowledge and without it, knowledge implementation cannot go the way we want it to be. Having enough information on any scope of knowledge support judgment in the knowledge use and create high decision making in what anyone can plan to do. Books are silent philosophers; we should make them speak for us to harvest what we need from them. Book will not explain something to you, you the one to explain what are in the book. If you wait books to explain what are in them, enough knowledge will be not be gotten, thus, being curious to know the meaning of what contains the book will help you to explain what the book is about.

\section{You will never know any thing until you know yourself- Dr. Callixte Yadufashije}

Knowledge is very important for us and without knowledge life can be impossible on the planet. Knowledge creates life. knowledge is sometimes individual and everyone has his own knowledge. Knowledge I need is not knowledge anyone needs; everyone has particularity for knowledge need in the life of the planet. Any cause of learning should be based on what you need from knowledge. If you need nothing from knowledge, why do you learn? Since knowledge is not used, it late becomes useless. Interpretation of knowledge in us should be given time for us to analyze type of knowledge we need and how knowledge will contribute in what we need. I can say, I need knowledge in chemistry. But why do I need knowledge in chemistry? Is for me to work in different chemical industries? Is for me to be a teacher of chemistry? Is for me to a researcher in chemistry? Different critics can take place for anyone to know why he/she needs any scope of knowledge. Knowing yourself is important if you want to know something. You cannot know anything if you don't know what you could know. Self-identification is important for anyone to know him/herself. no one will know all sciences, no one will know all languages, no one will cooperate with all people and no one is supposed to know everything. The way we identify ourselves is the way of discovering ourselves and this leads to the discovery of what we need and what we need tell us the type of knowledge we need. It is amazing if you are asked why you are a pharmacist, and you reply it is because my friends also are pharmacist. Who are matters in what you can achieve and some people are not aware on who they are and what they are capable of. It is always difficult to achieve what you want if you don't know yourself. If you don't know yourself, you will know nothing, but you know yourself, you will be ready to identify what you are supposed to know 
and who you need for any knowledge you need. everything you need are based on you, friends you need are based on you and failing knowing yourself is failing at all. it is a task and responsibilities of anyone to know him/herself before knowing anyone or anything else. You should know yourself for to know what you need to know. We need to know our inner person, we need to know our outer person for us to be ready for everything and out of this nothing will be done wisely. It doesn't matter on your status, you should be you in everything, don't be anyone else. Strive to know yourself for to know more about the nature and harvest from it.

\section{Nothing is good from tragedy except learning for bright future- Dr. Callixte Yadufashije}

Tragedies are not really good for our life as none can wish to enter them voluntarily. Tragedies are sometimes a reference to what you will achieve or what you have already achieved. Tragedies are difficult times in life, they stress us and sometimes take our life away. To remember tragedies, you have gone through and how you have sort out from them increase the moral of working hard and achieve much from your work. Nothing actually good in tragedies but if anyone sort out from tragedies, you become strong them and no longer fearing complex problems as you have experienced passing through them. Everyone should know that the world is not a straight line, and what others are facing can reach him/her in one way to another. The context of this notice, will prepare you to be ready fighting in all situations even if no wish to go through tragedies. Tragedies are tests of life, and you succeed in a certain test, the confidence rises and no longer think on fails as you experienced success. Working under pressure of tragedies increase the will of anyone to work hard more than expected for sorting out from tragedies. Despite bad outcomes from tragedies, it is sometimes through tragedies that we get success. Those who experienced tragedies and get success are good people to learn from them, they have different ways of solving problems on the planet. Nothing is easy from tragedies but also no capacity that human being has to stop tragedies as some tragedies comes randomly and reach us. We cannot stop tragedies to reach us but we have capacity to fight against tragedies, although capacity of fighting against tragedies comes from experience of facing them, and learning from tragedies makes us strong even if is not a wish to face them. It is always difficult to face tragedies and solve them without much of struggles, which means that tragedies create struggles for people, and these struggles train people to be strong and learn to problems for themselves. Learning to solve problems is important for mankind as we will always face them, that's why sometimes tragedies play a huge role of making us problem solvers if we resist from their consequences. If you have faced different difficult situation, I am sure that you have something to speak than anyone else. Don't wish to be strong in peaceful situation, learn to be strong in difficult situation. The proof of how strong you are, is justified by how you solve problems, not only on how you enjoy peaceful situations. You are strong because you are able to resist in various situations of life, not because you have zero problems. Tragedies are good teachers to take us far in problem solving, we cannot wish to face tragedies but we could be ready to fight against them so that we do not fail if they reach us.

\section{No one can teach beyond his/her capacity of learning- Dr. Callixte Yadufashije}

Teaching and learning is two terms that are used in education. In school education they are those who learn and those who teach. What is amazing is that those who teach should understand that are them who need to learn much. The way we learn, is the same way we teach. A teacher teaches what he/she has learned either from teachers, friends, books and environment and no any other source of knowledge except these ones. You learn to teach and what you learned are what you will deliver during your teaching process. Teaching is done in different ways not only classes teaching because we always learn from different sources. You can teach during conversation, you teach during singing, you teach during in public speeches, and you teach through the way you behave to others. We should note that we are source of knowledge in one way to another. If we are source of knowledge through mentioned way, then, de we have what to deliver for those who need to learn from us? Is the content clear for those who need to learn? Are we sure that what people learn from us take them where they want to go and give them knowledge they wanted? We cannot 
be teachers if we have never learned enough. We need to make sure that what have learned are clear and enough to teach ourselves and others. Teaching others is our responsibility in one way to another but what we teach should be evaluated to see if it will positively impact who we are teaching. It is difficult to accept that you can teach differently from what you have in mind; it is impossible to affirm that you will teach chemistry if you have not learned chemistry enough to the teacher of it. those who want to be good teachers learn much for life. each and every practice has its own equipment for knowledge production. Teachers should be curious to see the outcome of what they have taught. Creating knowledge is something great to anyone, and if you have been a creator of what someone's knows, it is something to celebrate. Nothing better than contributing on what other have known. If we need to deliver enough content of what teach, we should rise the capacity of learning. Learning to have enough knowledge to deliver should take enough time in us, and should be for always not really for a period of time. Teacher need enough knowledge than students. Teacher teach and share his/her experiences to make sure that what he/she teaches are understood by learners/students. In the future students will share what they have learned from teachers, they will cite their teachers and give examples from their previous teachers. If you learn less, you teach less, and teaching less is proof that you have learned less at all. the way you rise your capacity of learning is the same of rising the capacity of teaching. Learn much to teach much and note there is no fail in positive learning.

\section{I don't know not because I don't know anything, I don't know because I am always curious to know- Dr. Callixte Yadufashije}

In life we always learn. no one knows everything, and if no one knows everything why do we stop learning. Wise people always feel to have enough knowledge as they believe to be creator of life and knowledge in the on the globe. Most of the time you can feel us if you know nothing, not because you know nothing but because of the level of what you want to know. It seems always difficult to fill the gap of knowledge for those who wish to know the maximum of something. To be curious of something leads to exploration of it for you to have enough information on it. those wish to know the maximum of what they should know, sometimes suffer from emptiness in their inner for what they know. They mostly ask themselves if what they know are enough for them to be satisfied. Those who are curious to know much are them who know much than those who think that they know much. To be curious to know something is not the meaning of the absence of knowledge but is the meaning of wisdom. Wise people do not feel that they have done with knowledge, they always such for knowledge to avoid limitation in their lives. It doesn't matter on which level of education you have form you to acquire knowledge, it requires to be curious on type of knowledge you need to have. Some of people learn for life, they born learning and become old learning and this is because they want to fill their inner gap of knowledge. If knowledge continues increasing gaps in what we know, are we sure that we have knowledge? If the gap continues to be unfulfilled, do we really have knowledge or not? It should be clear for these kind of people, they have knowledge but always wish to have different various things in terms of knowledge you should have. The type of knowledge for curious people is different, they are not curious to know what they don't know and what they think they can have enough knowledge for them to be successful in life. curious people do waste their time to learn one thing for long time, they take their time and finish what they can finish for to have the next step tomorrow. To be curious of knowledge shows the high level of intelligence you have reached. Those who think that they have finalized with knowledge find themselves old in what they know. Knowledge should be modernized in space and time. Application of knowledge is something important and itself shows the level of knowledge you have and knowledge you still need in what you are doing. Note that unused knowledge expires. Feel empty of knowledge not because you are empty but because you want to be smart in what you know. Some people think on knowledge for job purpose only but this doesn't take long as it leads to fails in one way to another. Knowledge is more than searching job, knowledge is more than having masters or Doctorate degrees, knowledge is more than the position you are having, knowledge should be permanent tool to be used to reach at maximum level of your dreams. if you are scientist you should feel sciences, should deliver sciences, and should be a reference to others. If you have not attained to be a reference to others, why do you stop learning as if you have maximized what you have supposed to do? Having enough knowledge means to be a good asset for 
those who need knowledge, to a source of knowledge for different people requires enough knowledge and experience. Try to apply knowledge in different context for to verify whether knowledge you have is enough. Accept to challenge your knowledge for you to know more. Unchallenged knowledge has no meaning at all. being curious of knowledge is the beginning of knowledge needed than thinking that you have maximized what you have supposed to know without justification. If the world change. how do you explain that you have achieved enough to stop from where you are? Be curious of knowledge for you to have knowledge and apply knowledge to justify what you know, but also expand your knowledge to have experience and share your experience for you to be wise. You cannot be curious to know if you don't challenge what you know.

\section{People who fear fails are failers of life- Dr. Callixte Yadufashije}

The life we live in is about trying to reach the goals and dreams of our will. This shows reality of life we are living in. we should try for us to save our life on the planet and if we fail trying it ends up by the end of life. in each and every trial we should expect either positive or negative outcome from the trial. It should be understood for everyone that if anyone fails to try he/she fails life of him/herself but all for others. Some of us do not understand in the same way this concept of life trial, but you will reach nothing if you have invested nothing. You should try and fail and if you fail, you will learn from mistakes. Failure is not something easy to accommodate, but also you cannot enjoy success if you never tasted failure. Those who succeed after failing value their success and master how to manage failure in case it comes to them. How can be curious to win if you have never faced failure? It is not a wish for anyone to fail but life we live in is straight, we always try for us to make a way for better living. It is easy to fail if you have never faced failure, but it is not easy to fail if you have faced failure as you have enough experience to manage and apply surveillance to avoid failure. Thus fearing failure do not mean to avoid it, it means to increase its speed to reach you. If you fear failure, you will not be able to fight against it, it will come whether you want or not and will fail you because you are not trained enough to fight against it. if you fear failure, you will not try life at required level for you to be successful. Failure is part of life as success is. Failure should not be our choice in what we are doing for us to learn, but if it comes, we could learn how manage it. if you continue fearing that you can fail, you will later fail and this kind fail is inevitable. Continuing life trials is something important for us to reach our life destination if we have it. we should have life destination for us to be complete and prove that we are humans. If we do not have life destination, could we say that we are different from other livings? We should always try in life, of course challenges will fight against us but we later develop immunity to resist to challenges. It doesn't matter on how many times you have failed in your trial. $<<$ It seems always impossible until it's done, Said Nelson Mandela the first president of the republic of South Africa $>>$ try and try don't stop trying because if you stop, this is where failure comes. Nothing is for nothing, nothing will come to you random, investing our effort in what we are doing is the first invisible success at starting page of our life trial journey.

\section{If you value who you teach, you learn by teaching- Dr. Callixte Yadufashije}

Teaching is always done from primary schools to Universities. The high percentage of students have intention to learn from their teachers and mostly believe that what their teachers taught are correct. Students carefully listens to their teachers for them to have what they do in exam, tests and others different evaluation that show what a student have learned during the course. On the other hand, teachers prepare themselves to teach a good content that will support student to have knowledge required at the end of the lesson. At the end of the lesson the teacher assesses his/her students for him to see the level of knowledge students have after the lesson. All of these are for knowledge creation. Teachers also are assessed by directors for them to see if he/she has done with the course and whether students understood what the teacher have taught. Students use their concentration to know what teachers are teaching and sometimes do not sleep for them to sure that they have knowledge in the course taught. Even if students use their effort, the low number of teachers think to learn from their students. Both teaching and learning are knowledge sharing and it could be a big loss if only students learn from teachers and teachers share what he/she has without sharing with students to hear their views. Teachers should learn from their students if they value them. Students are not 
empty containers, they have knowledge received from different sources, they have been interacting with environment more than enough to have a certain capacity, they are good source of knowledge to teachers. Learning is not sitting and become a student, learning could be having knowledge through different ways. You can observe something and gain knowledge form it and other strategies. Teachers should learn how to create knowledge for themselves from their students. The way teachers create knowledge is to give time for students to explore the course and come sharing what they have learned from their deep exploration of the topic. The way students share what they searched about the course, it is the same way teachers learn new fact from what students have discussed. Students are good teachers to teachers and teachers should not reject these opportunities. A good teacher can be a teacher and on the other had a student. None knows everything, we always learn and if you stop learning, you later become ignorance. A teacher should not build only on what he/she has already known; he/she should learn new facts in all steps of their profession. Teachers mostly spent their time with students, which means that students could be their primary source of knowledge. Traditional education allowed students to sit and hear what the teacher is teaching but without suggesting their views. Limiting student in terms of sharing their thought on the course is the enemy of knowledge creation and can later lead to low critical thinking bother teachers and students. The way students value what their teachers teach could be the same way to teacher to value students 'views. If students are trained to be source of knowledge, their level of thinking will be high and teachers will learn much from them, but if students are taught to memorize only what teachers have said, there is no longer become intelligent at the required level. Teachers should be a pearl of knowledge creation through considering students as source of knowledge in each process of learning, however, teachers should remember to share their experience to learn for students to have a starting point.

\section{I don't have much to say on wisdom, but consider yourself wise if you are in touch with reality- Dr. Callixte Yadufashije}

Wisdom is always used in philosophy and other related sciences. You will hear people saying that some is wise, but is there any instrument used to measure wisdom? Mostly we can say that someone is wise because he/she has knowledge of any particular thing admirable. Differentiating knowledge from wisdom has been a big challenge to many of us. The level knowledge that anyone has do not show how wise he/she is; any level of education does not justify how wise anyone is. Wisdom is independent in one way to another. You cannot be wise if you are far from reality. Wisdom without reality do not exist and will never exist. Anyone can wonder if he/she is wise, but the response is one, you are wise if you are in touch with reality, you are wise if you apply principles of reality in what you are doing. Those who discovered principles of reality become wise in all steps of their life. A wise person freely think in positive way than wasting his/her time in negative things, a wise person accept suggestions and judge all to select what suits his/her goals, a wise person knows that everything can change and predict for solutions, a wise person like achievement of others as he wish to achieve, a wise person do not look at personal interest but mostly common interest, a wise always try for better change, a wise person respect all without entering people life, a wise person knows that what he knows could be good if something added. They are different qualities of a wise person, but reality is the best justification of what wisdom is. If a wise person has money today, he/she knows that sometimes can be without money. A wise person knows that if he has food today, it is also possible to hungry in some situations. Nothing impossible for wise people except impossible things in life. reality shows that you are wise or not, reality measures wisdom level of anyone, reality is not corrupted to give false results of who you are except bad interpretation of those who want to create their own reality, and own reality will no longer be late to fail you in what you are doing. Wisdom is the guide of our thought, wisdom is the guide of goals and wisdom is the planner of the long term vision. Consider yourself wise if you feel you are in touch with reality, consider yourself wise if you understand things as they should be, consider yourself wise if you understand the nature the way it is. 


\section{There is nothing else differentiating believers and non-believers except imagination- Dr. Callixte Yadufashije}

The word believer is mostly used to mean those who believe in God as their creator and the coordinator of everything happening on the planet. Interchangeably, the word non-believer is used to mean someone who do not believe in God, who don't even accept God as a creator of mankind. Non-believers believe that they can work for them to have what they need in their lives; they don't believe in miracles or anything that tells them that it exists because of God. But what is the difference between these people? do believers have justification of what they believe? If justification is ontological how do justify beliefs without facts? Believers mostly think that they are different from non-believers, but this has no justification. What makes them different is how they understand things and how they imagine. Beliefs can create new understanding and you later think that what you believe is reality but that is not what it means as all we are true are not reality. A non-believer can tell you that there is no God since no one has seen it, on the other hand, a believer can tell you that since we do not know where we came from or where everything thing comes from is the justification of the existence of God. Imagination creates a new fact in an individual, however, reality accepts imagination that later enters existence. Both believers and non-believers have different imagination, but mostly believers do not accept that what they believe are imagination despite absence of proof. It doesn't matter on how people understand and imagine things if it doesn't negatively affect themselves and the community. Imagination affects the inner person either positively or negatively. Thinking that there is someone who will give what we need through miracles will stop and limit the creative capacity of anyone who believe in this principles. Believing that you are under control of superpowers long gives you freedom of thinking independently as you fear what superpowers will decide for you. Believing on the heaven and the hell takes enough time in our lives, wondering where we will be after death is discussion of importance but longer wondering where we have been before our physical existence on the planet. Fearing death has been a fact of accepting eternal life through the belief of God and the Savior Jesus. These beliefs are mind adaptation. Mankind has everything through knowledge and choice he has in his capacity compared to other animals, but we need to think also where animals will go after this life we think will end by the coming of the savior Jesus. We need to avoid accept what we cannot justify but also keep in mind that what we don't know do not exist. Analysis of what we believe. Imagine than you believe, work than you pray, be you than waiting to be something else, be productive than believing miracles, and be a miracle than believe miracles you have never seen.

\section{Don't be the teller of lies about stories of others, if you can't be the teller of truth about stories of yourself- Dr. Callixte Yadufashije}

Stories are parts of enjoyment of mankind, and build our joy in different ways. When people discuss they sometimes tell stories about their friends, sisters and neighbors. Being happy to talk about stories of others and sometimes you are not sure is not worth living at all. it's almost no nonsense to talk about lies on stories of others for accusing and destroy their images. There is no interest about telling lies about stories for us to be taken innocent than them. Before telling stories that you are not sure learn to be realistic, tell what you only know and avoid adding what you don't know as it sometimes destroys not only you but also others. Even if truth of the story is known, there is no need of talking about it if you don't want to learn from it. if you train the brain to tell lies about stories, you will later find yourself the destroyer of the community around and no longer the community believes you as an important person for them. Before starting telling a story about stories of others, you need to start from yourself. You speak what you know from others but what do you know about yourself, is clear to start from yourself? Everyone knows him/herself than anyone else, and if this is true, why do I need to start from stories of others than stories of yourself. Telling a story doesn't matter it contain truth and if it doesn't harm anyone of us. If telling stories will harm some of us, there is no need of it. we do not need to talk about lies about stories of others if we hide truth about stories of ourselves. Being realistic in what we discuss with friends shows who we are in our inner. The way we lie in what we tell be will later disqualify us in one way to another. Telling a store should have a purpose and the purpose 
should have o good outcomes for those who heard you telling them the story. Having an interest of telling lies about stories of others is destroying the way of living, who you tell story will also have his/her free time to analyze what you have been telling him and will know the reality of what you have been talking about. The best of telling a story is first to think on why and how? Why do I need to talk about this story, how will it affect the listeners of it? will increase anything on my status? if the one that the story belongs hears what I said to him/her/ will this be good to him/her? Will it create future conflict between us? After this you will be able to know the way of how and why you need to talk about a certain story otherwise it can lead of different negative outcomes, and what we don't want us to do for us could be stopped to others. Stories are good in our lives but let's have stories that create peace between us.

\section{You won't learn anything from others, if you've learnt nothing from yourself!- Dr. Callixte Yadufashije}

Learning is a process of acquiring knowledge. We always need to learn different things as we always find need to achieve number of things in one way to another. Learning from others is a significant thing in life and should be done with ourselves. Before learning from others it is better for us to learn from ourselves, who we are explains the capacity of learning from others. If you have learned from yourself, you are sure for what to learn from others. Note that whatever you learn could be a compliment of what you already have or what you have learned from yourself. Explaining what you need to learn from others without identification of what you have explored from yourself could lead to learning nothing at all. Taking enough time to learn what you know and what you are capable of is important and longer cause failure to anyone. What you need from others will depend on what you have, and if you feel you have nothing, you need to go slowly for you learn much about yourself. Learning from yourself prevent you to copy what others have done, but learn from what they did. Copying and learning are not the same, if you learn from what others have done, you observe what they did and outline the way they passed through to reach where they are or to have what they have, then you think how you can implement what you what to do through the same ways but in your own ways. But on the other side, if you want to copy what others have done, you follow the same instructions, you go through the same way without changing, and if the budget required, you use the same budget, but note that sometimes you are not able and have no capacity to reach what who you are copying did, which lead to failure of what you are doing. Learn for you to have ways of doing things on your own, don't learn to copy from others. To know what you know before deciding what to learn from others is key of learning the true content, but learning before knowing what you know no longer give a good harvest for any plan of life. what you have learnt from others will be fruitful through the way you implement them for your own, learn and be ready to understand things in your context, don't understand things in the context of who you are learning from. understanding of yourself is key to understand what you are learning in your context, and this will lead to the better of knowledge you learnt from others without difficulties. The need for learning is in everyone who has a clear vision and who want to work for his/her dreams using his/her capacity, but for our dreams to come true, different interventions are important that is why we need to learner from great achievers of life. the great intervention in what we do should come from ourselves and what we learnt from others could be an added value. Learn from yourself before learning from others to avoid failure, and learn from others to build a great suitability of what you are doing. Maximize in learning in learning from yourself if you want to maximize what you will learn from external sources.

\section{During judgement of your crime, you can lie any judge from anywhere for you to be innocent, but you cannot lie your inner person the greatest judge of your crime!- Dr. Callixte Yadufashije}

Innocence sounds great for mankind and every one wishes to be innocent at all. however, some question could be asked: am I innocent? Which kind of innocent do I have? Which kind of innocence do I need? this questions are important. Externally, innocence can be created by everyone for social justification. Inner person is wider than anyone can think. Innocence cannot be measured easily by anyone if there are justification. Crimes could have facts for someone to be punished and without facts, there are punishments 
can be given. Innocence is known by the inner person than anyone else, and no one can discover about this if there no facts. Sometimes, during judgements, you can be innocent when you have crime due to your capacity of justifying how innocent you are. Acceptance of your justification for you to be innocent, do not always mean your innocence. What you justify could be accepted and external innocence will show people that you are innocent and will remove all punishments that you are supposed to be given. The inner person continue itself judging you even if you have been judged and made innocent by judges. The inner person continues showing you how criminal you are and this will later destroy your Seoul and no longer you act as a human in what you are doing. Reality is the good measure of innocence for everyone, and better to focus on true innocence than edited innocence. If we want to be innocent and have inner peace we could work innocently and no longer the inner person judges us. The greatest peace that anyone can have is the inner peace and the absence of inner peace kills the Seoul for number of people. Inner will can be the creator of the inner innocence. Inner innocence is greater than external innocence. Instead of learning how to lie for you to be innocent, you can use enough time learning how true innocence can be your choice and how you can reach it. Note that you cannot lie and succeed in each case of crime, for this don't train yourself to be a criminal person even if you have facts justifying you. To be criminals should not be voluntarily, anyone can face criminal cases, but cannot be a choice. Whoever you are, learn to be innocent than learning how to make yourself innocent without innocence in your inner person.

\section{When it comes to comparison, an eye blind person is wiser than a brain blind person- Dr. Callixte Yadufashije}

Comparison is always done in mathematical sciences to sometimes measure superiority, inferiority and equality. Commonly, a blind person is someone who has impairment of vision. This term is used for those whose eyes cannot see. On the other side, brain is important part of mankind that coordinates all activities in our life and without it, nothing can be possible for the life we have on the planet. The worst blindness if the blindness of the brain, the blindness of the brain means the death of a person. If the brain becomes blind, there is no longer a person works as person. You cannot positively think with blind brain and nothing can be possible at this case. The way we train the brain to be will lead to blindness of it. the way we act in what we are doing will affect the brain activities and become blind. The blindness of the brain is different from blindness of eyes. The brain is blind if the owner is not doing things correctly the way it should be done. The way we try to go far from reality, is the same way we become blind in our brain. The mindset we have justify how smart the brain is or how blind the brain is. Our peer groups show how smarty the brain is. What we are busy of makes the brain smart of blind. The investment we use in what we are doing makes the brain smart or blind. The vision you set shows how the brain is and no longer unsmarted things tolerate our brain. If the brain is trained to only receive, the brainer will become the receiver, but if the brain is trained to give or to offer, the brain will become the giver. If the brain is trained to only receive, the brain will be blind to give. The blind brain cannot be productive and no progress can be waited from blind brain. If someone wants you to be blind, he will support blindness of the brain because the brain makes yourself. There is no longer you reach what you want if you are blind in your brain. Those who are blind of eyes know that they blind but those who are blind of brain know nothing about their blindness. You know something because your brain tells you that you know it but if the brain is blind, how will you know about yourself? An eye blind person can think positively and tells you something great which can be fruitful for you in one way to another, but a brain blind person can be even a destroyer of what you can achieve as he/she is not ready to see the reality. An eye blind person knows that people are important for him/her as they support him/ her to live, but sometimes, a brain blind person thinks that he/she is enough in him/herself. The blindness of the brain is terrible in anyone achievement and is barrier to the future of anyone. The brain should be protected from being blind through accepting principles of reality.

\section{Wisdom is a creator of free thinking, while free thinking creates free mind and free mind creates inspiration- Dr. Callixte Yadufashije}

Wisdom has been discussed in different books of sciences, social sciences, and philosophy. But how 
do we become wise? Can knowledge makes us wise? Can environment makes wise? Can understanding makes us wise? Wisdom means the quality of being wise. Some books define wisdom as the ability to use knowledge and experience to make good decisions and judgements. From this short definition, wisdom could be understood. The way we use knowledge shows how wise we are, the way we take decisions shows how wise we are, the way we judge shows how wise we are. Another important thing that the wisdom is about is experience. What do we mean by experience? Is work experience of the work? Yes of course the experience of the work is included. Experience of personal life is more important to make you wise. Individual observation is a great thing that create the inner experience. People should expose themselves to experiences for them to be wise. You can wait to be old for you to have experience and be wise. Learning how knowledge can be productive is the way of wisdom creation in what we are doing. Learning from physical existence creates a good experience and support all decisions that can be taken in our lives. Knowledge is not enough for anyone to be wise, but the way through which the knowledge is used makes you wise. Knowledge should be use in wise way for the best harvest from it. the way we use knowledge we have support the way we see things and this create free mind. Wisdom creates free thinking through the way it supports decision making. Taking good decisions for long, makes you free in everything you are doing. The way that freethinking develops in an individual, it is the same way that the mind becomes free and free mind starts inspiring people around you. Free mind is an inspired mind and inspired mind inspires.

\section{Out of Humanistic, friendship becomes nothing- Dr. Callixte Yadufashije}

Friendship is term used to mean the relationship between friends. Friendship is created because of different things. In daily life we meet friends may be coworkers, classmates, and others. Friendship is important for our lives, friends take care of us in different ways, friend give us advices in what we are doing, friends give us information we need, friend visit us, friend build the inner peace in our lives. Those are positive outcomes of friendship but of course it has negative outcomes. Identification of friends we have should be in our daily home works. We need to know types of friends we have, and we need to know why people make us their friends. We could not create friendship for our own profit only. They are what we need from friends, and they are what friends need from us, and this is where we talk about humanism. What you need, your friends also need the same, the good life you need, your friends also need the same life. the future you need. your friends also need the same. Any friendship between people will have no meaning if it goes far from reality of humanism. Being humanistic in friend create long term friendship as friends see potential in you and do not wish to lose you. Before thinking what your friends will do for you, you need to think what you will do for your friends. If you only think what friends will do for you, it seems that they love you but you don't love them. If you love from each other, your future will be collective not really individual. Friendship without life changes has no meaning and means wasting of time. We need to humans before anything else, we need to be humanistic before entering friendship relations. Being humanistic create a principle of being important to others, and gives you power to work hard and be productive to others. Friends need you the way you need them; they can depend on you the way you depend on them. Better to have friends that you need to help than those you think they will help you. Having people to support makes you grow in terms of thinking big. Avoiding selfishness in friendship is to create humanism in friendship but if anyone use selfishness in friendship, there is no longer his/her friends think on him/her. Good friends work together for their development. Friends advice from each other, good friends wish everyone of them to develop and change lives. In friendship some us forget the reality of being humanistic in their friendship which limit the development of their friendship. Between friends, there is love and no love with selfishness. Love accepts to forgive mistakes, note that your friends can do mistakes for you, as you can commit a mistake to them, you can learn to forgive them and they should learn to forgive you. To be humanistic will protect your friendship and will ever last. To be humanistic will tell you what to do for friends and will stop selfishness in what you are doing in friendship. Whatever you engage in friendship be a human and not that what you need is also what your friends need. to be humanistic will be the guider for your friendship and will build honesty in friendship. 


\section{Remember that all people with light are not right people for you, you only need to know right people for you to have light- Dr. Callixte Yadufashije}

Right and light are two words used differently. Light is important in life for us to see and know where we are going. Light fights against darkness in all situation. We use right mostly to mean something correct. In what we do we need people, we need others for us to reach our goals and dreams. people we need should be right to us. People with light are not always right people to us, light you need is of yourself, you do not need light from others for you to fight against darkness, you need your own light to fight against it. You need right people who can shape you to have light and reach direction of your dreams. All people with light are not for you, all people with light are not ready to give you light and is not always good to copy their light for you to be the right person you wish to be. Who is a right people you need? how does he take you? Right people you need is someone who give you the value, is someone who cannot destroy your ideas, is someone who gives clear advice in what you are doing, and is someone who can sacrifice for you. If persons you are with are this, they are right people you need and you will have light you need very soon. In many ways, we do think that people we need are people with high personalities, with big families, and, maybe it can be true, however, they are sometimes busy to be with us and have no time to have an interest to us. It for great value to know who you need and how you will access him/her. who we need can be an accessible person, can be a reachable person and can be the person who has time for us right persons are essentials for us to have light and we will never have light if we are not with right people. we will remain in permanent darkness if we are with false people, a right people has no any special characteristic. Those we think are not important for us, they can be right people to us. The selection of right to be with should be done with much attention for us to have right people who will create light for us. With right there is no light. 


\section{ACKNOWLEDGEMENTS}

None can achieve something without intervention from different people who supported him/ her in different ways. My first gratitude is addressed to different people who took their time to read and share my quotes in different people from different environments and backgrounds. I cannot forget people who encouraged to write many quotes, they have been engine that accelerated me to think more than I was for the production of these quotes. I cannot forget to express my profound appreciation to Fr. Dr. Fabien Hagenimana, Vice Chancellor of INES-Ruhengeri-Institute of Applied Sciences for his time taken to through my quotes and important encouragements given are highly appreciated. I thank everyone who participated during the production of this book including Those who commented on quotes through different media, your ideas and encouragement are for great value.

Discover a bigger Impact and Visibility of your article publication with

\section{Peertechz Publications}

\section{Highlights}

* Signatory publisher of ORCID

* Signatory Publisher of DORA (San Francisco Declaration on Research Assessment)

* Articles archived in worlds' renowned service providers such as Portico, CNKI, AGRIS, TDNet, Base (Bielefeld University Library), CrossRef, Scilit, J-Gate etc.

* Journals indexed in ICMJE, SHERPA/ROMEO, Google Scholar etc.

* OAI-PMH (Open Archives Initiative Protocol for Metadata Harvesting)

* Dedicated Editorial Board for every journal

* Accurate and rapid peer-review process

* Increased citations of published articles through promotions

* Reduced timeline for article publication

Submit your articles and experience a new surge in publication services (https://www.peertechz.com/submission).

Peertechz journals wishes everlasting success in your every endeavours. 


\section{Callixte Yadufashije*}

Callixte Yadufashije, Researcher in areas of medical microbiology and preventive medicine and Senior lecturer and director of research and consultancy at INES-Ruhengeri-Institute of Applied Sciences, Rwanda, Tel: +250788273428; E-mail: cyadufashije@gmail.com; cyadufashije@ines.ac.rw 